\title{
U.S. state policies for renewable energy: Context and effectiveness ${ }^{\text {is }}$
}

\author{
Magali A. Delmas ${ }^{a, *}$, Maria J. Montes-Sancho ${ }^{\mathrm{b}}$
}

a UCLA Institute of the Environment and Sustainability and Anderson School of Management La Kretz Hall, Suite 300, Los Angeles, CA 93106-5131, United States ${ }^{\mathrm{b}}$ Department of Business Administration, Carlos III University, Madrid, Spain

\section{A B S T R A C}

Over the past decade, state policies on renewable energy have been on the rise in the U.S., providing states with various options for encouraging the generation of renewable electricity. Two promising policies, the Renewable Portfolio Standard (RPS) and the Mandatory Green Power Option (MGPO), have been implemented in many states but the evidence about their effectiveness is mixed. In this paper, we argue that recognizing the natural, social, and policy context under which MGPO and RPS are adopted is necessary in order to measure their true effectiveness. This is because the context rather than the policy might lead to positive outcomes and there is the possibility for sample bias. When controlling for the context in which the policies are implemented, we find that RPS has a negative impact on investments context in which the policies are implemented, we find that RPS has a negative impact on investments
in renewable capacity. However, we find that investor owned utilities seem to respond more positively to RPS mandates than publicly owned utilities. By contrast, MGPO appears to have a significant effect on installed renewable capacity for all utilities regardless of the context in which it is implemented.

\section{Introduction}

Addressing climate change has become an important priority for the U.S. administration. In the U.S., greenhouse gas emissions come primarily from the combustion of fossil fuels in energy use. Energy related carbon dioxide emissions, resulting from the combustion of petroleum, coal, and natural gas, represented $82 \%$ of total U.S. anthropogenic greenhouse gas emissions in $2006 .{ }^{1}$ While the U.S. generates $3 \%$ of its electricity from renewable resources, ${ }^{2}$ other developed countries such as Denmark, Germany, Spain, and New Zealand generate $25 \%, 20 \%, 16 \%$, and $8 \%$ of their electricity from renewables, respectively. ${ }^{3}$ In addition, all of the European Union member states have aggressive renewable energy percentages they plan to reach by 2020 , while the U.S. has no federally defined targets for renewable generation. ${ }^{4}$

We thank Carley Markovitz for her exceptional research assistance with this project.

onding author. Tel.: +1 3108259310 .

E-mail addresses: delmas@ucla.edu (M.A. Delmas)

mmontes@emp.uc3m.es (M.J. Montes-Sancho).

1 http://www.eia.doe.gov/bookshelf/brochures/greenhouse/Chapter1.htm

2 This is without hydroelectricity. Biomass (71\%) was the predominant nonhydro renewable fuel for electricity generation in 2003 , followed by geothermal and wind. Solar thermal and photovoltaics together accounted for less than $1 \%$ of the U.S. non-hydro renewable generation. http://www.eia.doe.gov/cneaf/solar. renewables/page/non_hydro/nonhydrorenewablespaper_final.pdf.

3 EIA, 2009. International Energy Statistics. http://www.eia.doe.gov/emeu international/electricitycapacity.html.

4 "Europe's Energy Portal." http://www.energy.eu/\#renewable
While there are current debates about the implementation of a federal renewable policy, U.S. states have taken a leading role in establishing renewable energy policies since the late 1990s. These include Renewable Portfolio Standards, the requirement to sell green products, disclosure policies, and subsidies. Analyzing the effectiveness of state renewable policies can be helpful to inform the current policy debate at the federal level.

Recent research has started to look at the effectiveness of state policies on the generation of renewable electricity but has found mixed results. While some studies have found positive results (Bird et al., 2005; Delmas et al., 2010; Menz and Vachon, 2006; Zarnikau, 2003; Yin and Powers, 2010), others have found no significant results (Carley, 2009).

Furthermore, most of these studies provide little information on the natural and institutional conditions under which state renewable policies are adopted, which could have an impact on their effectiveness. For example, the relationship between installed renewable capacity and a state's resource endowment (e.g., sun, biomass, or wind) is unclear with some studies finding negative correlations (Carley, 2009). There is also little informa tion on how the institutional context facilitates the effectiveness of renewable policies. Without taking into account the natural and institutional context we might falsely attribute effectiveness to the policy. It is possible that investments in renewables could have happened in the absence of the policy just because the context was favorable. In addition, differences in policy effective ness might vary according to the type of electric utilities that are subjected to these policies as electric utilities investing in renew able capacity have different governance structures. Some of them 
are investor owned while others are publicly owned. We argue that these differences might explain disparities in responses to state policies.

In this paper, we analyze the impact of two major and related policies on the capacity of renewable energy: Renewable Portfolio Standards (RPS) and Mandatory Green Power Options (MGPO), which request electric utilities to source or sell specific percen tages of renewable energy. Our analysis differs significantly from previous research. First, we integrate in our model state and electric utility characteristics to understand both the context of adoption and effectiveness of state renewable policies. Second, we analyze capacity development rather than changes in the percen tage of total generation from renewables as this provides a better indication of changes in the renewable infrastructure.

Overall, our results indicate that different renewable policies have different effects on the development of renewable capacity. As hypothesized, Green product requirements are found to be more effective than RPS. Our findings also indicate the importance of modeling the factors that trigger policy adoption to analyze policy effectiveness. When modeling such factors, the effect of RPS on renewable capacity becomes negative and significant, while it was insignificant with the previous methodologies used in the literature. In addition, we find that different types of utility react differently to the policies. For example, RPS seems to be more effective at getting investor owned utilities to invest in renewable capacity as compared to publicly owned utilities.

This paper is organized as follows. In the first section, we review state renewable policies and the literature on their effectiveness. In Section 2 we present our empirical analysis based on the analysis of the strategies of 650 U.S. utilities from 1998 to 2007. In Section 3 we describe our results. A concluding discussion follows.

\section{State renewable energy policies}

Renewable state energy policies are usually grouped into two categories. The first category provides financial incentives to encourage renewable energy. These include tax incentives, grants, loans, rebates, and production incentives (Menz and Vachon, 2006). The second category contains rules and regulations, which mandate a certain action from an obligated entity. Included within this category are Renewable Portfolio Standards, Manda tory Green Power Options, and fuel disclosure rules (Menz and Vachon, 2006). In 2007, all but three states (Alabama, Alaska, and Mississippi) had implemented at least one of these policies, and four states (Colorado, Iowa, Oregon, and Washington) had estab lished all four policies (see Table A1 in the Appendix). While each of these renewable energy policies has its own implications and may deserve additional analysis, this paper will focus primarily on two policies requiring electric utilities to source or sell renewable energy: Renewable Portfolio Standards (RPS) and Mandatory Green Power Options (MGPO).

The concept of a renewable portfolio standard dates back to 1983, the year when the first RPS policy was enacted in Iowa (Wiser et al., 2007; Wiser and Barbose, 2008). RPS requires electricity providers in those states to source an increase in amount of renewable energy in a specified timeframe (Vachon and Menz, 2006). The majority of states give their electric utility providers the option of generating electricity from renewable resources themselves, and/or exchanging renewable energy cred its (RECs) or renewable energy certificates, in order to meet RPS mandates (Carley, 2009). The amount of renewable energy a utility is required to provide from renewable resources can be measured in absolute units (KW or $\mathrm{KWh}$ ) or as a percentage of total retail sales (Wiser et al., 2007). In the state of Oregon, RPS requires that large utilities supply $25 \%$ of electricity from renew able resources by 2025 , whereas smaller utilities must provide between $5 \%$ and $10 \%$ by $2025 .^{5}$

The Mandatory Green Power Option (MGPO) requires electri city suppliers to provide an option for their customers to purchase green power either directly from their electric company or from an alternative provider (Menz, 2005). The electric companies have the option of generating renewable energy themselves, purchas ing green power from an alternative producer, or buying renew able energy credits from their state's public utilities commission (Menz and Vachon, 2006). MGPO represents a more recent option than RPS and has been adopted by six states.

In addition to RPS and MGPO, tax incentives and fuel dis closure programs are popular approaches used by state govern ments to increase renewable energy production. Sixteen states employ corporate income tax credits for solar and wind invest ments, as well as for the utilization of green electricity (Menz, 2005). ${ }^{6}$ Currently established in 24 states, disclosure programs impose requirements upon companies to impart information on the fuel sources used to produce the electricity they provide directly to their customers (Delmas et al., 2010). For example, the Minnesota disclosure program requires electric utilities to submit biannual reports that contain a pie chart depicting the mix of fuel sources, a bar chart of air pollutant emissions, a chart of costs associated with different generating sources, and a discussion of energy efficiency measures (Delmas et al., 2010). Essentially, disclosure programs are implemented with the intention of increasing consumer awareness of the inner workings of their electric companies, with the hope that elevated knowledge will ignite more thoughtful decision making on the part of the consumer.

\section{Literature review}

Overall, the research conducted on the effectiveness of RPS has found mixed results. For example, Carley (2009) found that RPS was not significant as an effective state renewable energy policy. Delmas et al. (2007) also reported that RPS was not significant in impacting renewable generation. On the other hand, Menz and Vachon (2006) concluded that RPS had a significant and positive impact on wind capacity and Yin and Powers (2010) also concluded that RPS was a positive effect on the development of renewable capacity. While these studies report differing results, it is important to recognize that they used different dependent variables: generation of renewable energy, and wind and renewable capacity. The effect of RPS on the generation of renewable energy was not significant, whereas its effect on wind capacity and renewable capacity was positive and significant.

Because MGPO is a more recent policy, there are fewer empirical studies on its effectiveness. Menz and Vachon (2006) found that Mandatory Green Power initiatives have a positive and significant impact on the development of wind capacity in electric utilities' fuel mix ratios. Yin and Powers (2010) report the same results on electric generation capacity.

The results of the research on the effect of other renewable policies such as financial incentives are mixed. Carley (2009)

\footnotetext{
${ }^{5}$ Database of State Incentives for Renewables and Efficiency (DSIRE). http:// www.dsireusa.org/incentives/incentive.cfm? Incentive_Code=OR22R\&re=1\&ee=1.

${ }^{6}$ In addition, 14 states implement a sales tax exemption on solar photovoltaic, wind energy, and other renewable energy equipment. Twenty-six states also either completely exempt renewable electricity sources from property taxes, or implement a price reduction for green electricity in residential, commercial, or industrial buildings (Menz, 2005).
} 
found that subsidies have a positive and significant correlation with the generation of renewable energy, while tax incentives have a negative and significant correlation. Menz and Vachon (2006) found that Public Benefits funds (PBF) were not significant to predict wind capacity at state. Delmas et al. (2010) report that financial incentives, specifically tax incentives, have no effect upon the fuel mix ratios of electric utilities. Menz and Vachon (2006), as well as Bird et al. (2005), found financial incentives to be insignificant in enhancing wind power capacity. Disclosure policies are found to be more positive at encouraging renewable energy. Delmas et al. (2010) found that mandatory disclosure programs have a positive and significant effect upon a firm's generated fuel mix: the existence of mandatory disclosure pro grams increases the amount of renewable sources provided by electric utilities, and decreases the amount of fossil fuel sources. This is consistent with the analyses of Green Power Demand, undertaken by Zarnikau (2003) and Roe et al. (2001), who conclude that disclosure policies have a positive and significant impact on consumers' willingness to pay for green power.

The variance in the data thus far accumulated on the efficacy of renewable energy policies produces an inconclusive overall picture. We argue that the current literature suffers from a methodological weakness because most studies do not control for what is called a potential "sample selection," a type of bias caused by choosing non random data for statistical analysis. Indeed, the decision to adopt a renewable policy, such as RPS and investments in renewable capacity is likely to be influenced by the same factors. In other words, there might be a sample bias in that the reason why a policy is adopted might be related to its success. Self selection makes it difficult to determine causation. For example, one might note significantly higher capacity invest ments among those states that have adopted renewable policies, and credit the policies for the difference. However, due to self selection, there are a number of differences between states that have adopted policies and states that have not. Arguably, those that adopted policies might have been better endowed in renew able resources or might have had more highly motivated policy makers than those that did not, and such differences in resources and dedication may have affected investments in renewables in the two groups. If such was the case, then it is not meaningful to simply compare the two sets of scores.

Research in related fields found that such sample selection problems were present in studying the effectiveness of voluntary policy programs (Anton et al., 2004; Delmas and Montes, 2010; Khanna and Damon, 1999; Rivera, 2002; Rivera and DeLeon, 2004). While several papers have analyzed the drivers of the adoption of state renewable policies (Lyon and Yin, 2010; Vachon and Menz, 2006), these papers did not relate the factors that explain the adoption of renewable policies to the effectiveness of the policies. For example, Vachon and Menz (2006) found that social and political interests were positively linked to the adop tion of green electricity policies while the renewable potential (measured as the percent of sales that can be provided from renewable resources) was not significant. Lyon and Yin (2010) focused on RPS and found that states with poor air quality, strong democratic presence, organized renewable developers, and strong wind potential were more likely to adopt an RPS.

In this paper, we propose to use a different estimation model than those used previously, in order to determine simultaneously the adoption of RPS at the state level and the determinants of a firm's decision to invest in renewable capacity. In this, we build on research that was conducted in the policy and management field (Green et al., 1996; Delmas and Tokat, 2005; Delmas and Montes, 2010; Khanna and Damon, 1999; King and Lenox, 2000; Rivera, 2002; Rivera and DeLeon, 2004; Vandenberghe and Robin, 2004; Welch et al., 2000).
In addition, most studies in the literature focused primarily on the generation of renewables rather than investments in renew able capacity. With only one exception (Yin and Powers, 2010), those that did focus on capacity focused exclusively on wind (Bird et al., 2005; Menz and Vachon, 2006) rather than on total renewable capacity. While relatively small portfolio shifts are easily obtainable by altering capacity utilization, purchasing or building new facilities may be required to dramatically alter fuel mix portfolios. The majority of the current literature, by focusing on renewable generation, might analyze changes in capacity utilization rather than shifts in capacity. In our paper, we focus on the effect of renewable energy policies on the building of energy infrastructure, which will be critical for the development of green power in the future. Evidence shows that several serious obstacles impede the building of new capacity, including financial regulations and the acquisition of permits. Indeed, according to PG\&E's Jennifer Zerwer, "It's difficult to project [renewable capacity] given the unknowns of permitting, financial, technolo gical and transmission capacity issues."7 We believe that by analyzing renewable capacity rather than renewable generation, our paper will be able to take into account such obstacles to evaluate the effectiveness of policies on the renewable infrastructure.

In addition, the majority of the discussed papers analyzed the adoption of renewable energy at the state level rather than analyzing firm level strategies. Our approach therefore also differs from these papers as we examine how differentiated utilities, either public or privately owned, respond to renewable energy policies by increasing renewable capacity.

In conclusion, the literature has found mixed results regarding the effectiveness of renewable policies and suffers from several limitations. First, the studies do not control for potential sample selection and do not model the decision making process of adopting the policy to understand its effectiveness. Second, most studies use as a measure of effectiveness generation of electricity from renewable energy rather than installed capacity. Finally the analyses are done mostly at the state level rather than at the firm level, and to not identify how different types of utilities respond to these policies, as policy effectiveness might vary accordingly.

\section{Hypotheses}

First, we should expect different levels of effectiveness between RPS and MGPO because of the difference in the design of these two policies. Second, because electric utilities have different governance structures, we should also expect a different impact of renewables policies upon publicly owned utilities than on privately owned ones. Third, in analyzing renewable capacity rather than renewable generation, we should expect that the natural and institutional conditions under which a policy is put into place will have an impact on the effectiveness of the policy.

\subsection{RPS and MGPO}

Renewable Portfolio Standards have been implemented in more than half of the states in the U.S. and many regions of the world, and different terms have been used to define it. For example, in the UK, it is called "Obligation" and in Denmark "Quota Obligation." The main idea is that the electricity portfolio of electric utilities must include a specific percentage of power generated from renewables. Although RPS has been described in

${ }^{7}$ Sullivan, Colin. "Renewable Energy: Calif. utilities still hunting for power to meet RPS." Contra Costa Times 30 June 2009. LexisNexis. Web. 
policy circles as a "market friendly" approach to achieving renewable energy targets because it does not mandate a specific allocation of government money (Solsky and Bielenberg, 2004; Wiser et al., 2007), RPS in fact resembles a command and control policy where the regulator requires the producer to adopt a specific technology. In other words, RPS focuses on the use of a specific technology rather than directly addressing emissions and focuses on increase in supply rather than demand.

Because RPS lacks a market dimension, implementation and enforcement of the policy is a key component of its potential success. Pressman and Wildavsky (1973) have emphasized the importance of the policy implementation process as key to policy success. Some elements identified by Pressman and Wildavsky (1973), which can lead to delaying implementation, include the number and variety of participants at each decision point, the preference of the participants, and how it evolves over time. In the case of RPS, it is possible that the political gains of adopting the policy were enough for those enacting the policy and that over time enforcement was not a priority for the adminis tration (Michaels, 2008; Rossi, 2010). As Michael mentions, RPS are politically easy to implement because: "It is easy to specify legislatively and the cost of compliance might be more easily concealed in utility bills than an outright tax on conventional power or subsidy to renewables." (Michaels, 2008, p. 86). But "having enacted seemingly stringent new standards, legislators may have little to gain politically by vigorously enforcing them" (Michaels, 2008, p. 107).

In fact, RPS in most states allowed flexibility in the imple mentation and did not have strong enforcement mechanisms. Many RPS policies include flexibility provisions that exist to assist suppliers in achieving RPS targets. A "true up period" is a three month period in which suppliers are allowed to acquire the necessary RECs, or make up any shortfall in renewables targets (American Wind Energy Association, 1997). Credit banking also exists, which allows generators and renewable energy suppliers to "bank" credits indefinitely, allowing for an unspecified period of time for them to make up any shortcomings in RPS goals. Lastly, a force majeure provision allows for a further extension of the "true up period" in cases of uncontrollable situations, such as natural disasters, so that affected providers are not penalized unnecessarily for compliance failures (American Wind Energy Association, 1997). Force majeure provisions, also categorized as escape clauses, vary depending upon the state. The majority of states with RPS have an outlined escape clause, although some states have no specified clause, such as New York and Massachu setts. ${ }^{8}$ Although the policy specifies that utilities that do not comply with RPS requirements may suffer penalties, there is no evidence of strict enforcement of RPS programs, since there is no record of penalties paid in the U.S. (Solsky and Bielenberg, 2004).

In conclusion, because RPS resembles command and control regulation, it is likely to be ineffective at increasing investments in renewable energy capacity when associated with lax enforce ment mechanisms. We therefore hypothesize the following:

H1. RPS is ineffective at increasing investments in renewable energy capacity.

MGPO requires utilities operating in the state to offer and publicize green power options to consumers and provide a more direct link than RPS to a potential demand effect. MGPO allows customers to support the purchase of electricity from renewable energy sources by their utilities. The principle of MGPO is that

\footnotetext{
${ }^{8}$ Union of Concerned Scientists, 2008. Renewable Energy Portfolio Standard Summary http://www.ucsusa.org/assets/documents/clean_energy/massachusetts. pdf and http://www.ucsusa.org/assets/documents/clean_energy/new-york.pdf.
}

consumers may increase demand for fuels perceived as envir onmentally favorable and decrease demand for fuels perceived as environmentally unfavorable. This mechanism requires several preconditions. First, that consumers are willing to pay for renew able energy and that there is choice among electricity products. However, the mechanism does not require choice among elec tricity providers.

An emerging literature suggests that consumer awareness changes in response to environmental information (Desvousges et al., 1992; Blamey et al., 2000; Loureiro, 2003; Loureiro and Lotade, 2005; Leire and Thidell, 2005). Existing research reports customers purchase of green power (Bird and Swezey, 2003) and positive willingness to pay (WTP) for green energy electricity premia (Byrnes et al., 1999; Ethier et al., 2000; Gossling et al., 2005; Zarnikau, 2003; Bergmann et al., 2006). Borchers et al. (2007) demonstrate a positive WTP for green energy electricity. Further, the specific green energy source affects WTP. In fact, individuals do exhibit preferences for solar versus a generic green or wind source. Biomass and farm methane are found to be the least preferred sources. Some studies have shown the extent of customer participation in green pricing programs.

As of 2007, the total number of green customers was $835,651 .^{9}$ Premium prices fluctuate depending on the customer's monthly electricity bill, but one tends to pay between 3 and 12 dollars per month for a green electricity premium (Zarnikau, 2003). While residential green customers may not make up a significant demand for green electricity, some evidence suggests that non residential users play an increasing role in the demand for green electricity. The limited research conducted suggests that up to $60 \%$ of businesses indicates a willingness to pay a premium for green power (Wiser et al., 2001). In addition, green power programs that target non residential customers have seen over $20 \%$ of green power sales attributed to those customers (Wiser et al., 2001). The U.S. Environmental Protection Agency publishes the National Top 50, a list of the organizations leading the way in annual green power purchases. Corporations such as Intel, Pep siCo, Whole Foods Market, and Kohl's Department Stores are at the top of the EPA's list. ${ }^{10}$ PepsiCo and Whole Foods Market, for example, can boast having $100 \%$ of their total electricity from green power resources. ${ }^{11}$ As a part of their "Green Mission" section on their website, Whole Foods stated: "We were the first major retailer to offset $100 \%$ of our energy use with wind energy credits. And we are glad to see that some of the world's largest retailers are following the example we've set in green building, the use of solar power, company wide recycling programs, inter nal green mission programs and support for organics. When more companies take green steps, we all win."12

We argue that such a potential increase in demand can trigger electric utilities' interest in power generation as they see a potential for attracting green consumers to purchase green power at a premium (Delmas et al., 2007). An increase in demand within the state will have an effect on the production of renewable energy within the state, a portion of which will be undertaken by electric utilities that are also selling the electricity. Because MGPO is market oriented, utilities incentives should be more aligned with the policy than they are with RPS and facilitate its implementation of the policy. We therefore hypothesize that MGPO will be effective at increasing investments in renewable energy capacity.

\footnotetext{
${ }^{9}$ http://www.eia.doe.gov/cneaf/solar.renewables/page/greenprice/green_pri cing.html.

10 "National Top 50." Green Power Partnership, the U.S. Environmental Protection Agency. http://www.epa.gov/grnpower/toplists/top50.htm.

11 http://www.epa.gov/grnpower/toplists/top50.htm.

12 "Values and Actions: Green Mission." Whole Foods Market. http://www. wholefoodsmarket.com/values/green-mission.php.
} 
H2. MGPO is effective at increasing investments in renewable energy capacity.

In conclusion, we expect differing effectivenesses between RPSs and MGPO. While we expect an insignificant effect of RPS on investments in renewable energy capacity, we expect a positive effect of MGPO.

\subsection{Electric utilities governance}

Investor owned electric utilities are privately owned enter prises (Electric Power Industry Overview, 2007). ${ }^{13}$ Investor owned utilities provide electricity for approximately 100 million individuals, about $71 \%$ of the country's total consumer base (Electric Power Industry Overview, 2007) ${ }^{14}$ In comparison, pub licly owned electric utilities are local nonprofit organizations. Public utilities represent roughly $61 \%$ of the total number of electric utilities and supply approximately $9 \%$ of generating capability, and account for about $15 \%$ of retail sales (Electric Power Industry Overview, 2007). ${ }^{15}$ Publicly owned utilities acquire their financing from the sale of general obligation bonds and from revenue bonds secured by proceeds from the sale of electricity (Electric Power Industry Overview, 2007). ${ }^{16}$

As private companies, investor owned utilities are motivated primarily by turning a profit, and the constituencies with the greatest influence on their financial wellbeing are their custo mers. According to Stuart Hemphill, Southern California Edison's vice president of Alternative and Renewable Power, the point of aggressively pursuing renewable energy contracts is that "every contract we execute for renewable power is good for the industry, our customers, and the environment." ${ }^{17}$ Scholars have shown that under deregulation the freedoms conferred on utilities and the competitive threats that they face elicited differentiation strate gies based on green power products (Delmas et al., 2007). These strategies can lead to green power products succeeding in the marketplace because of the emergence of customer classes that were suppressed under regulation by its historical accounting practices and lack of incentives for innovation. Free to offer green power options, utilities can use such initiatives to differentiate themselves in ways that reflect their new realities under dereg ulation. We should therefore expect electric utilities to be more responsive to renewable policies that allow them to offer green power products.

However, just as investor owned utilities want to prioritize their customers' demands, they are reliant upon their state's PUC in order to do so. Because PUCs determine the rate a utility is allowed to earn, and therefore the rate that the utility will eventually charge to its customers, PUCs have a great effect upon investor owned utilities and their subsequent financial success (Bonardi et al., 2006). Publicly owned utilities are governed by their "consumer owners," who may be locally elected or appointed officials. ${ }^{18}$ Many utilities rely on the local governing body, such as the city council, to regulate their actions. ${ }^{19}$ Within

\footnotetext{
${ }^{13}$ They operate in all states except Nebraska, where electric utilities consis primarily of municipal systems and public power districts.

${ }^{14}$ They represent $6 \%$ of the total number of electric utilities and approximately $38 \%$ of utility installed capacity, $42 \%$ percent of generation, $66 \%$ percent of sales, and $67 \%$ percent of revenue in the U.S.

15 As of 2007, there were 2009 publicly owned electric utilities in the U.S.

${ }^{16}$ Electric Power Industry Overview (2007). Energy Information Administration.

17 "Southern California Edison Launches 2009 Solicitation for Renewable Power." Business Wire (2009).

${ }^{18}$ American Public Power Association (APPA). http://www.appanet.org/uti lity/index.cfm? ItemNumber $=9857$ \&navItemNumber $=21031$.

19 In 2005 , the APPA reported that $60 \%$ of publicly owned utilities are governed by a city council, while the remaining $40 \%$ are governed by an independent utility board. http://www.appanet.org/utility/index.cfm?ItemNum
}

the Los Angeles Department of Water and Power (LAWPD), for example, each member of the Board of Water and Power Commis sioners is appointed by the mayor for a five year term. So publicly owned utilities might be more responsive to local governing bodies than investor owned utilities that might be more respon sive to the policies issued by their PUCs at the state level.

Furthermore, investor owned utilities are more likely to have the technical capabilities and financial resources to add on increments of renewable power in comparison to public utilities. This would include experience managing a diverse portfolio of energy types (Fremeth, 2009).

In conclusion, because investor owned and publicly owned utilities respond to various stakeholders and have different capabilities, we hypothesize a differing effect of renewable policies on their investment in renewable capacity. We expect that investor owned electric utilities will be more likely to respond positively to renewable policies based on their capabil ities and the potential for environmental differentiation strategies associated with some of the policies.

Hypothesis 3. Investor owned electric utilities will be more responsive to renewable policies than publicly owned utilities.

\subsection{The context of renewable policies}

While policies might have different potential for effectiveness due to their design and according to the type of utility imple menting them, we argue that we need to control for the environ ment (natural, social, and political) in which renewable policies are adopted, since this can have an impact on their successful implementation.

First, the natural context should be examined as a potential factor in the implementation and effectiveness of renewable policies. The renewable energy industry depends on natural capital defined as "the stock that yields the flow of natural resources" (Daly, 1996, p. 80) or indispensable resources and benefits, essential for human survival and economic activity, provided by the ecosystem. As argued by Russo, renewable natural capital such as wind or solar is difficult to move around and geographic specific (Russo, 2003). While it has been shown that it might be easier to implement policies in states with a higher endowment in natural resources (Vachon and Menz, 2006; Lyon and Yin, 2010), it is unclear whether the natural resource endowment alone can drive the effectiveness of renewable policies. For example, Carley (2009) found that a state solar potential was significant and positive at explaining the total $\mathrm{MWh}$ of renewable energy electricity while the wind and biomass endowment variables were negatively associated with renewable electricity.

Indeed, scholars have argued that natural capital must be com plemented by social and political capital to drive the adoption of renewable policies and the development of new technologies and investments in renewable resources (Lyon and Yin, 2010; Russo, 2003; Sine and Lee, 2009; Vachon and Menz, 2006). For example Russo showed that industry associations and the number of existing renewable projects helped the development of new projects. Sine and Lee (2009) found that environmental groups had a larger impact on entrepreneurial activity in the wind energy sector than the avail ability of natural resources. Similarly, Vachon and Menz (2006) and Lyon and Yin (2010) found that political and social interests were positively and significantly related to the developments of renewable energy projects. Regarding the political factors, Carley (2009)

(footnote continued)

ber=9857\&navItemNumber=21031. Managing Ethical Challenges by William Atkinson. 
found that a green political index (measured by the League of Conservation environmental scores for the House) was positively related to renewable generation, but that regulatory restructuring was negatively related to renewable generation.

Because these natural, social, and political factors have been shown to facilitate the development of renewable policies and also of energy investments, it is important to take them into account in order to isolate the effect of a renewable policy. It is indeed possible that there are a number of differences between states that have adopted policies and states that have not in terms of natural, social, and political factors, and that these factors, rather than the policy implemented, might have explained differ ences in investments in renewable energy. In conclusion, in line with previous studies, we expect that natural, social, and political capital will facilitate the adoption of renewable policies and investments in renewable energy. Thus in order to isolate the effect of policies and control for self selection bias, we need to use econometrics methodologies that simultaneously predict the adoption of renewable policy and the determinants of a firm decision to invest in renewable capacity.

\section{Methodology}

To test the effectiveness of RPS and MGPO policies, we used a two stage modeling technique that controls for self selection (Heckman, 1978). This two stage estimation determines simulta neously the adoption of RPS at the state level and the determi nants of a firm's decision to invest in renewable capacity.

In the first stage regression, we present a binomial logit to predict the adoption of the renewable energy policy at the state level. This model provides an estimation of the likelihood that a given state will adopt a renewable energy policy.

The adoption model in the binary logit model is specified as follows (first stage):

$\operatorname{Prob}\left(\right.$ Renewable policy $\left._{i, t}=1\right)=F\left(Z_{i, t-1}^{\prime} \beta\right)$

(Model1a)

where Renewable policy is the binary dependent variable of this first stage. This variable represents the decision of the state to adopt a renewable policy. It takes a value equal to 1 the year of enrollment and the following years and 0 otherwise. $Z_{i, t-1}$ is the set of exogenous independent variables that explain the decision of the state to adopt a renewable policy, and $F$ is the cumulative logistic distribution $\left(F(x)=e^{x} /\left(1+e^{x}\right)=1 /\left(1+e^{-x}\right)\right)$. The indepen dent variables are used with 1 lagged year to avoid reverse causality.

In the second stage regression, we use the predicted values of renewable policies to test whether these explained renewable capacity at the firm level. Because the distribution of the capacity variable is skewed and the data are censored at zero, conventional regression methods cannot be used. Instead, we use a Tobit model, which assumes that the distribution of the error term is normal and the estimation explicitly takes limit and non limit observations into account (Greene, 2008). ${ }^{20}$ We include fixed effect factors for years. ${ }^{21}$

${ }^{20}$ We tested whether the residuals of our regressions are normally distributed. We performed the Skewness and Kurtosis, the Shapiro-Wilk, and the Shapiro-Francia tests for normality, which do not reject the hypothesis of normal distribution. Hence it is appropriate to use the Tobit model for our data. The Shapiro-Wilk test is based on Shapiro and Wilk (1965) and the Shapiro-Francia test is based on Shapiro and Francia (1972). The Skewness and Kurtosis tests for normality are based on a combined measure of skewness and kurtosis of the data (D'Agostino et al., 1990; Royston, 1991).

${ }^{21}$ Unconditional fixed-effects Tobit models may be estimated but the estimates are biased (STATA 7, 2001, p. 474). We also ran a random effects model. Unfortunately, the quadrature approximation underlying the estimation of the
The second stage regression is presented below:

Renewable capacity $_{i, t} \quad \delta$ Renewable policy $_{i, t}{ }_{1}+X_{i, t}^{\prime}{ }_{1} \gamma+\varepsilon$

(Model1b)

where the variable Renewable capacity is the dependent variable that we use to measure the effectiveness of renewable policies. Renewable policy ${ }_{i, t}{ }_{1}$ is the predicted probability of adopting a renewable policy obtained in the first stage using binary logit, and $X_{i, t-1}$ is a set of control variables that could also explain invest ments in renewable capacity. Renewable policy and the set of control variables are one year lagged.

In order to test the effect of renewable policies on investments in renewable capacity, we collected data from a number of sources to assess investment in renewable capacity, renewable policies, state characteristics, and electric utility characteristics. The variables are described below and in Table A2 in the Appendix. The variables included in the first stage regression are consistent with previous studies (Carley, 2009). In the second stage, we added a variable related to the type of electric utility, namely investor owned and publicly owned. The sample consists of 650 electric utilities in 48 states for the period 19982007 , with $1 / 3$ of investor owned utilities and $2 / 3$ of publicly owned utilities. The firms in our sample represent $72 \%$ of the electricity produced by utilities in the U.S. from 1997 to 2007. The states of Alaska and Hawaii are not included in the analysis due to lack of available data on natural resources.

The main dependent variable is renewable capacity. The vari able is defined as the sum of the maximum rated output of all units owned per utility (thousand of MW). Information was obtained from the Energy Information Administration Form 860.

\subsection{Renewable policies}

We collected data from the Database of State Incentives for Renewables \& Efficiency (DSIRE) to gather information on RPS, disclosure policies, tax incentives, and the MGPO.

\subsubsection{Renewable Portfolio Standard}

This variable captures the effect of operating in a state with an established RPS (Delmas et al., 2007). We first create a variable that takes the value 1 if the state had an RPS in place and 0 if otherwise. For multi state utilities, this variable is weighted based on the percentage of electricity produced within each state by the utility.

\subsubsection{Mandatory Green Power Option}

The MGPO is a policy adopted by certain states that requires the state's electric utilities to offer "green power" to its custo mers, either through their own generation or through the pur chase of renewable energy credits (RECs). The variable takes the value of 1 if a state has implemented MGPO, and 0 if otherwise.

\subsubsection{Disclosure policies}

Some states require electric utilities to provide their customers with specific information about the electricity that the utility supplies. This information, which must be shared with customers periodically, usually includes the utility's fuel mix percentages and emissions statistics. We create a variable on disclosure based on the enacted year, where the value of the variable is 1 for the

\footnotetext{
(footnote continued)
}

random-effects model is problematic in our data set and the parameter estimates of the random-effects model are not stable. Two aspects of random-effects models have the potential to make the quadrature approximation inaccurate: large group sizes and large correlations within groups (STATA 7, 2001, p. 476). These factors can also work in tandem, decreasing or increasing the reliability of the quadrature. Therefore, we do not report them in this paper. 
Table 1

Logit Model of the adoption of Renewable Portfolio Standards and MGPO.

\begin{tabular}{|c|c|c|}
\hline & $\begin{array}{l}\text { RPS } \\
1997-2006\end{array}$ & $\begin{array}{l}\text { MGPO } \\
2001-2006\end{array}$ \\
\hline RPS & & $\begin{array}{l}5.88^{* *} \\
(2.31)\end{array}$ \\
\hline Disclosure & $\begin{array}{l}-0.83 \\
(0.59)\end{array}$ & $\begin{array}{l}0.42 \\
(0.99)\end{array}$ \\
\hline Wind resources & $\begin{array}{l}1.14^{* * *} \\
(0.22)\end{array}$ & $\begin{array}{l}1.57^{*} \\
(0.83)\end{array}$ \\
\hline Solar resources & $\begin{array}{l}0.52^{* * *} \\
(0.12)\end{array}$ & $\begin{array}{l}-1.10^{* *} \\
(0.45)\end{array}$ \\
\hline Biomass resources & $\begin{array}{l}-0.59^{* * *} \\
(0.19)\end{array}$ & $\begin{array}{l}-1.18^{*} \\
(0.64)\end{array}$ \\
\hline Deregulation & $\begin{array}{l}0.62 \\
(0.69)\end{array}$ & $\begin{array}{l}0.16 \\
(1.82)\end{array}$ \\
\hline Democratic governor & $\begin{array}{l}0.24 \\
(0.47)\end{array}$ & $\begin{array}{l}2.41^{* *} \\
(1.03)\end{array}$ \\
\hline Democratic representative & $\begin{array}{l}0.04^{* *} \\
(0.02)\end{array}$ & $\begin{array}{l}0.17^{* * *} \\
(0.05)\end{array}$ \\
\hline League of Conservation Voters & $\begin{array}{l}0.07^{* * * *} \\
(0.01)\end{array}$ & $\begin{array}{l}-0.02 \\
(0.04)\end{array}$ \\
\hline Sierra membership & $\begin{array}{l}-0.25 \\
(0.25)\end{array}$ & $\begin{array}{l}-1.53^{*} \\
(0.87)\end{array}$ \\
\hline Renewable associations & $\begin{array}{l}5.92^{* * *} \\
(1.45)\end{array}$ & $\begin{array}{l}5.85^{*} \\
(3.16)\end{array}$ \\
\hline $\begin{array}{l}\text { Percent of electricity generated from } \\
\text { renewables }\end{array}$ & $\begin{array}{l}0.16^{* * *} \\
(0.04)\end{array}$ & $\begin{array}{l}-1.99^{* * *} \\
(0.42)\end{array}$ \\
\hline Emissions & $\begin{array}{l}0.53^{* * *} \\
(0.18)\end{array}$ & $\begin{array}{l}-6.10^{* * *} \\
(1.66)\end{array}$ \\
\hline Income per capita & $\begin{array}{l}0.18^{* * *} \\
(0.07)\end{array}$ & $\begin{array}{l}-0.50^{* *} \\
(0.20)\end{array}$ \\
\hline Unemployment & $\begin{array}{l}-1.54^{* * *} \\
(0.27)\end{array}$ & $\begin{array}{l}1.16 \\
(0.98)\end{array}$ \\
\hline Electricity retail price & $\begin{array}{l}0.04 \\
(0.13)\end{array}$ & $\begin{array}{l}-3.45^{* * *} \\
(1.04)\end{array}$ \\
\hline Constant & $\begin{array}{l}-25.42^{* * *} \\
(4.66)\end{array}$ & $\begin{array}{l}28.95^{* *} \\
(13.61)\end{array}$ \\
\hline Observations & 480 & 288 \\
\hline Pseudo $R^{2}$ & 0.634 & 0.715 \\
\hline Percent of correctly classified & 91.46 & 97.22 \\
\hline
\end{tabular}

Year dummies are included, but they are not reported.

${ }^{*} p<0.10$.

${ }^{* *} p<0.05$.

$p<0.01$.

year the policy was enacted and for all years thereafter, and 0 if otherwise. For multi state utilities, this variable is weighted based on the percentage of production within each state by the utility.

\subsubsection{Financial incentives}

This variable encompasses the index of corporate, sales, and property tax implemented in each state, dating back to 1975 (sales and property tax incentives) and 1976 for corporate tax incentives. The variable is calculated as the number of tax incentives implemented in each state until that year, ranging from 0 to 3. For example, if a state has two tax incentives in place, one in 1997 and another in 2005, the variable takes a value of 1 for the period 19972004 and the value of 2 for the period 2005 2007. As can be seen in Table 1, all states but two that have RPS or MGPO also have tax incentives or have none of these. Because of this co linearity issue it was not possible to include that variable in the first stage regression.

\subsection{States' natural resources}

We incorporate variables regarding the availability of wind, solar, and biomass in the state where the utility operates.

\subsubsection{Wind potential}

Wind energy potential has been systematically studied in the U.S. (Elliott and Schwartz, 1993; Elliot et al., 1987). Here, wind potential is measured by the sum of land (in $\mathrm{km}^{2}$ ) subject to all classes of wind, with environmental exclusions and moderate land use exclusions. Environmental exclusions are defined as large natural areas including parks, monuments, wilderness areas, ecological preserves, and wildlife refuges where industrial, com mercial, and residential developments are restricted or very limited. Land use exclusions consider the 11 different land use categorizations (see Table 2). The states of Alaska and Hawaii are not included in the analysis due to lack of data.

\subsubsection{Solar potential}

Solar potential is defined by the ratio of insolation, which is the monthly average daily total radiation using input derived from satellite and/or surface observations of cloud cover, aerosol optical depth, precipitable water vapor, albedo, atmospheric pressure, and ozone resampled to a $40 \mathrm{~km}$ resolution. This information was obtained from the Solar Atlas provided by the National Renewable Energy Laboratory.

\subsubsection{Biomass potential}

As provided by Milbrandt (2005), the biomass potential vari able is defined as the total biomass resources available (per thousand tons) in each state.

\subsection{State characteristics}

We also include variables such as deregulation, Democratic governor, Democratic representative, League of Conservation Voters, Sierra Club, renewable association, income per capita, state emissions, unemployment, and electricity retail price all of which we categorize as state characteristics.

\subsubsection{Deregulation}

To pick up the effect of deregulation in the installed renewable capacity, we created a time changing variable that represents whether or not a retail deregulation policy had been enacted in a given state. Following Delmas and Tokat (2005) and Delmas et al. (2007), we created a time changing variable that takes the value of 1 starting in the year in which retail deregulation was enacted or a regulatory order was issued, and 0 otherwise. Some states, such as California, have suspended retail choice after years of deregulation. In these cases, the variable deregulation takes the value of 1 during the period where deregulation was active and 0 the suspended year and the following years. At utility level, this variable was weighted based on the percentage of electricity sold by the utility in each state. The information comes from the Energy Information Administration.

\subsubsection{Democratic governor}

We utilize a dummy variable indicating a Democratic gover norship, with 1 indicating the governor is a Democrat and 0 if otherwise. Information for the variable was obtained from the National Conference of the State Legislature.

\subsubsection{Democratic representative}

We incorporate this variable to test for the effect of ideological preference on the willingness to adopt state renewable energy policies. This variable is defined as the weighted percentage of House and Senate seats occupied by Democrats. Information is provided by National Conference of State Legislatures. 
Table 2

Tobit Model of Renewable Capacity (1998-2007) using enacted RPS year.

\begin{tabular}{|c|c|c|c|c|}
\hline & Model 1 & Model 2 & Model 3 & Model 4 \\
\hline RPS & $\begin{array}{l}0.05 \\
(0.06)\end{array}$ & $\begin{array}{l}-0.10 \\
(0.07)\end{array}$ & & \\
\hline RPS $\times$ Investor & & $\begin{array}{l}0.39^{* *} \\
(0.16)\end{array}$ & & \\
\hline MGPO & $\begin{array}{l}0.18^{* *} \\
(0.07)\end{array}$ & $\begin{array}{l}0.21^{* *} \\
(0.08)\end{array}$ & & \\
\hline Predicted RPS & & & $\begin{array}{l}-0.15^{* *} \\
(0.07)\end{array}$ & $\begin{array}{l}-0.37^{* * *} \\
(0.13)\end{array}$ \\
\hline Predicted RPS $\times$ Investor & & & & $\begin{array}{l}0.62^{* *} \\
(0.2)\end{array}$ \\
\hline Predicted MGPO & & & $\begin{array}{l}0.22^{* *} \\
(0.09)\end{array}$ & $\begin{array}{l}0.21^{* *} \\
(0.09)\end{array}$ \\
\hline Disclosure & $\begin{array}{l}-0.08 \\
(0.06)\end{array}$ & $\begin{array}{l}-0.07 \\
(0.06)\end{array}$ & $\begin{array}{l}-0.04 \\
(0.05)\end{array}$ & $\begin{array}{l}-0.03 \\
(0.05)\end{array}$ \\
\hline Financial incentives & $\begin{array}{l}-0.04 \\
(0.04)\end{array}$ & $\begin{array}{l}-0.03 \\
(0.03)\end{array}$ & $\begin{array}{l}-0.03 \\
(0.04)\end{array}$ & $\begin{array}{l}-0.02 \\
(0.03)\end{array}$ \\
\hline Wind resources & $\begin{array}{l}-0.00 \\
(0.01)\end{array}$ & $\begin{array}{l}-0.00 \\
(0.01)\end{array}$ & $\begin{array}{l}0.01 \\
(0.01)\end{array}$ & $\begin{array}{l}0.01 \\
(0.01)\end{array}$ \\
\hline Solar resources & $\begin{array}{l}0.01 \\
(0.01)\end{array}$ & $\begin{array}{l}0.00 \\
(0.01)\end{array}$ & $\begin{array}{l}0.01 \\
(0.01)\end{array}$ & $\begin{array}{l}0.00 \\
(0.01)\end{array}$ \\
\hline Biomass resources & $\begin{array}{l}0.02 \\
(0.03)\end{array}$ & $\begin{array}{l}0.03 \\
(0.03)\end{array}$ & $\begin{array}{l}0.01 \\
(0.03)\end{array}$ & $\begin{array}{l}0.02 \\
(0.03)\end{array}$ \\
\hline Deregulation & $\begin{array}{l}-0.11 \\
(0.08)\end{array}$ & $\begin{array}{l}-0.12 \\
(0.08)\end{array}$ & $\begin{array}{l}-0.17^{*} \\
(0.09)\end{array}$ & $\begin{array}{l}-0.17^{* *} \\
(0.08)\end{array}$ \\
\hline Democratic governor & $\begin{array}{l}0.00 \\
(0.00)\end{array}$ & $\begin{array}{l}0.00 \\
(0.00)\end{array}$ & $\begin{array}{l}0.00 \\
(0.00)\end{array}$ & $\begin{array}{l}0.00 \\
(0.00)\end{array}$ \\
\hline Democratic representative & $\begin{array}{l}0.01^{* *} \\
(0.00)\end{array}$ & $\begin{array}{l}0.01^{* *} \\
(0.00)\end{array}$ & $\begin{array}{l}0.01^{* *} \\
(0.00)\end{array}$ & $\begin{array}{l}0.01^{* *} \\
(0.00)\end{array}$ \\
\hline League Conservation Voters & $\begin{array}{l}0.00 \\
(0.00)\end{array}$ & $\begin{array}{l}0.00 \\
(0.00)\end{array}$ & $\begin{array}{l}0.00 \\
(0.00)\end{array}$ & $\begin{array}{l}0.00 \\
(0.00)\end{array}$ \\
\hline Sierra membership & $\begin{array}{l}0.09^{* *} \\
(0.04)\end{array}$ & $\begin{array}{l}0.10^{* * *} \\
(0.04)\end{array}$ & $\begin{array}{l}0.07^{* *} \\
(0.03)\end{array}$ & $\begin{array}{l}0.08^{* *} \\
(0.03)\end{array}$ \\
\hline Renewable associations & $\begin{array}{l}-0.08 \\
(0.07)\end{array}$ & $\begin{array}{l}-0.03 \\
(0.05)\end{array}$ & $\begin{array}{l}-0.04 \\
(0.06)\end{array}$ & $\begin{array}{l}0.03 \\
(0.05)\end{array}$ \\
\hline $\begin{array}{l}\text { Percent of electricity } \\
\text { generated from } \\
\text { renewables }\end{array}$ & $\begin{array}{l}0.00 \\
(0.01)\end{array}$ & $\begin{array}{l}0.01 \\
(0.01)\end{array}$ & $\begin{array}{l}0.01 \\
(0.01)\end{array}$ & $\begin{array}{l}0.01 \\
(0.01)\end{array}$ \\
\hline Emissions & $\begin{array}{l}-0.01 \\
(0.02)\end{array}$ & $\begin{array}{l}-0.01 \\
(0.02)\end{array}$ & $\begin{array}{l}0.00 \\
(0.03)\end{array}$ & $\begin{array}{l}0.00 \\
(0.02)\end{array}$ \\
\hline Income per capita & $\begin{array}{l}-0.00 \\
(0.01)\end{array}$ & $\begin{array}{l}-0.01 \\
(0.01)\end{array}$ & $\begin{array}{l}-0.00 \\
(0.01)\end{array}$ & $\begin{array}{l}-0.00 \\
(0.01)\end{array}$ \\
\hline Unemployment & $\begin{array}{l}-0.02 \\
(0.01)\end{array}$ & $\begin{array}{l}-0.02 \\
(0.02)\end{array}$ & $\begin{array}{l}-0.02 \\
(0.02)\end{array}$ & $\begin{array}{l}-0.03 \\
(0.02)\end{array}$ \\
\hline Electric retail price & $\begin{array}{l}-0.02 \\
(0.01)\end{array}$ & $\begin{array}{l}-0.02 \\
(0.02)\end{array}$ & $\begin{array}{l}-0.02 \\
(0.01)\end{array}$ & $\begin{array}{l}-0.02 \\
(0.02)\end{array}$ \\
\hline Investor owned utilities & $\begin{array}{l}0.12 \\
(0.05)\end{array}$ & $\begin{array}{l}-0.05 \\
(0.10)\end{array}$ & $\begin{array}{l}0.12 \\
(0.08)\end{array}$ & $\begin{array}{l}-0.10 \\
(0.11)\end{array}$ \\
\hline Green residential customers & $\begin{array}{l}0.03^{* *} \\
(0.01)\end{array}$ & $\begin{array}{l}0.03^{* *} \\
(0.01)\end{array}$ & $\begin{array}{l}0.03^{* *} \\
(0.01)\end{array}$ & $\begin{array}{l}0.03^{* *} \\
(0.01)\end{array}$ \\
\hline $\begin{array}{l}\text { Percent of generation from } \\
\text { fossil fuels }\end{array}$ & $\begin{array}{l}-0.13^{*} \\
(0.08)\end{array}$ & $\begin{array}{l}-0.12^{*} \\
(0.06)\end{array}$ & $\begin{array}{l}-0.14^{*} \\
(0.08)\end{array}$ & $\begin{array}{l}-0.11^{*} \\
(0.05)\end{array}$ \\
\hline Total customers & $\begin{array}{l}0.23^{*} \\
(0.12)\end{array}$ & $\begin{array}{l}0.24^{* *} \\
(0.12)\end{array}$ & $\begin{array}{l}0.22^{*} \\
(0.12)\end{array}$ & $\begin{array}{l}0.23^{*} \\
(0.12)\end{array}$ \\
\hline Constant & $\begin{array}{l}-0.39 \\
(0.49)\end{array}$ & $\begin{array}{l}-0.19 \\
(0.45)\end{array}$ & $\begin{array}{l}-0.64 \\
(0.53)\end{array}$ & $\begin{array}{l}-0.36 \\
(0.47)\end{array}$ \\
\hline $\begin{array}{l}\text { Observations } \\
\text { Pseudo } R^{2}\end{array}$ & $\begin{array}{l}5807 \\
0.353\end{array}$ & $\begin{array}{l}5807 \\
0.384\end{array}$ & $\begin{array}{l}5807 \\
0.354\end{array}$ & $\begin{array}{l}5807 \\
0.398\end{array}$ \\
\hline
\end{tabular}

Year dummies are included in all models, but are not reported.

${ }^{*} p<0.1$.

$\mathrm{p}<0.05$

$\mathrm{p}<0.01$.

\subsubsection{League of Conservation Voters}

Several researchers have used the scores of the League of Conservation Voters as a measure of the preferences of the elected representatives of a state (Delmas et al., 2007; Hamilton, 1997; Kassinis and Vafeas, 2002, 2006; Lubell et al. 2002; Viscusi and Hamilton, 1999). Each year, the League of Conservation Voters selects environmental issues to constitute an "environmental agenda," with a panel comprising the main U.S. environmental groups. The organization then creates an index by counting the number of times each representative or senator in Congress votes favorably on the environmental agenda (e.g., on the global warning gag rule, tropical forest conservation, or global climate change). The index ranges from 0 to 100 , with 100 representing a record of voting for the environmental agenda in all cases. The variable is the average of the environmental scores of the U.S. House of Representatives and U.S. senators of the states where each utility is operated (Kahn, 2002) weighted by the percentage of generation of each firm in each state for multi state utilities.

\subsubsection{Sierra Club}

In line with previous studies (e.g., Delmas and Montes, 2010; Helland, 1998; Kassinis and Vafeas, 2002; Maxwell et al., 2000; Riddel, 2003), we measure the environmental preferences of the population of the state in which a firm operates based on membership figures for one of the major environmental non governmental organizations, the Sierra Club. The measure itself is the number of dues paying Sierra Club members per 1000 state residents in each year.

\subsubsection{Renewable associations}

To determine the presence of renewable associations in each state, we utilized information provided by the American Solar Energy Society (ASES). Member chapters of the ASES include both solar and general renewables chapters.

Percentage of renewable generation. This variable is the percen tage of renewable generation, excluding hydro generation, over the total net generation of total electric industry at state level.

\subsubsection{Emissions}

This variable is a factor of $\mathrm{CO}_{2}, \mathrm{SO}_{2}$, and $\mathrm{NO}_{x}$ emissions at the state level. Information was found from the Environmental Protection Agency, Clean Air Market.

\subsubsection{Income per capita}

Using information obtained from the Bureau of Economic Analysis, we measure the median income per capita in each state. This measure of income is calculated as the income of the residents in a given area divided by the resident population of the area. The information comes from the Energy Information Administration, State Electric Profiles.

\subsubsection{Unemployment}

To further examine the economic situation on a state by state basis, we incorporated a variable on unemployment, utilizing unemployment rates provided by the Bureau of Labor Statistics.

\subsubsection{Electricity retail price}

This variable is defined by the average price for the total electricity industry (cents per $\mathrm{KWh}$ ) in each state. We used information obtained from the Energy Information Administra tion, State Electric Profiles.

\subsection{Electric utility characteristics}

We examine several variables to assess utility characteristics. This includes percentage of green residential customers, fuel mix of generated electricity, and total customers served by the utility 
and differentiated variables for publicly versus privately owned utilities.

\subsubsection{Investor owned}

To differentiate between investor owned and publicly owned electric utilities, we employ a dummy variable. Information describ ing the difference between investor owned and publicly owned utilities was found from the Energy Information Administration.

\subsubsection{Green residential customers}

This variable is the percentage of the number of residential customers who purchase electricity generated from renewable resources or pay for renewable energy development over the total number of residential customers served by the utility. The information comes from EIA, form 861.

\subsubsection{Percentage of generation from fossil fuel}

The type of technology a firm uses for generating electricity might explain its environmental strategies (Delmas et al., 2007). To account for these differences, we utilize the percentage of generation from fossil fuel using data from EIA, form 906 .

\subsubsection{Total customers}

Using information from Energy Information Administration, this variable reports the total number of customers (in millions) served by the utility.

\section{Results}

The first set of models is the logit models of the adoption of RPS and MGPO at the state level. The analysis is conducted for the years 19972006 for RPS and only from 2001 to 2006 for MGPO since there was no MGPO policy available before 2000 . Descriptive statistics are presented in Table A3 in the Appendix and the logit models are presented in Table 1 . The second set of models is the Tobit model of investments in renewables for the period 1998 2007. Descriptive statistics are presented in Tables A4a and 4b in the Appendix and the Tobit models are presented in Table 2.

The results from the logit models representing the adoption of RPS and MGPO show that these two policies were adopted in very different institutional contexts and in states with different natural resource endowments.

The variable representing wind resources is positive and significant to predict RPS and MGPO at the $1 \%$ and $10 \%$ levels, respectively. However, the variable representing solar resources is related positively and significantly to RPS but negatively to MGPO. Biomass resources are negatively related to both policies.

Regarding the political and social contexts, we find that the percentage of seats occupied by Democrats is positively and signifi cantly related to both policies. The presence of a Democratic governor is only significantly related to MGPO, while the League Conservation Voters are only significantly related to RPS. Sierra membership is negatively related to both policies but not significant (or only at the $10 \%$ level for MGPO). Renewable associations tend to play a sig nificant role in the adoption of RPS and MGPO policies, at the $1 \%$ and $10 \%$ levels, respectively. Deregulation and disclosure programs are not significant at predicting the adoption of the policies.

RPS is more likely to be implemented in states with a higher percentage of electricity generated from renewables and more emissions, higher income per capita, and lower rate of unemploy ment, while the opposite is true for MGPO. Retail price is negatively and significantly related to MGPO but insignificantly related to RPS.

In conclusion, while both policies were adopted in relatively similar political and social contexts, we find that they were adopted in very different economic contexts. The natural endow ment of these states also differs, with a higher endowment in solar energy for states that adopted RPS.

The models predicting renewable capacity are presented in Table 2. In these models we use enacted policy as the independent variable. In Models 1 and 2 we use the RPS variable (independently from the first stage regression) and in Models 3 and 4 we use the predicted RPS and predicted MGPO variables from the first stage regression. We find that the effect of the RPS variable on installed renewable capacity is insignif icant in Models 1 and 2. The effect of the predicted RPS is negative and significant in Models 3 and 4 when we present the results of the two stage model. Overall, we do not find that RPS is effective at explaining investments in renewable capacity. This confirms Hypothesis 1 . We even find a negative and significant effect for RPS when we control for the context of the adoption of RPS. This indicates a self selection bias that we corrected. The variable representing MGPO policies is signifi cant and positive in all models $(p<0.05)$, indicating a signifi cant effect of this policy on renewable capacity. This confirms Hypothesis 2.

In Models 2 and 4, we include an interaction term between RPS and investor owned utilities. This term shows to be signifi cant and positive $(p<0.05)$. This indicates that RPS is more effective at driving investor owned utilities to invest in renew able capacity in comparison to publicly owned utilities. This confirms Hypothesis 3. Regarding the effectiveness of other renewable policies, we do not see a significant effect for the disclosure and financial incentives variables.

We argued for modeling the context in which policies are implemented to measure their true effectiveness and found that the results for RPS differ when we do so. Models 3 and 4 show a negative and significant coefficient for RPS when the sign was insignificant in models 1 and 2 . The coefficient for MGPO does not change according to the different specifications. This might indicate that there is no sample bias associated with MGPO.

Turning to the state characteristics, the variables representing democratic representative and Sierra membership show to be significant and positive in all models and seem to be a better predictor of investments in renewable capacity than the presence of renewable associations or of high League Conservation Voters. State renewable potential (wind, solar, and biomass resources) is not significant at predicting investments in renewable capacity. The variable deregulation is negative in all models and significant in models $3(p<0.10)$ and $4(p<0.05)$. This is consistent with the findings of Kim (2009), who found that deregulation did not prove to be an effective mechanism for increase in renewable capacity.

As for specific utility characteristics, the percentage of green residential customers shows to be significant at predicting invest ments in renewables, as does electric utility size measured as the total number of customers. Firms with higher percentage of fossil fuels are also less likely to invest in renewable capacity.

We conducted several robustness tests. First, because we might expect that it takes time for the policies to be effective, we also conducted additional models using different time lags for the renewable policies as a robustness test (from two to five year lags). ${ }^{22}$ Overall these models present similar results.

\footnotetext{
${ }^{22}$ Results available upon request from the authors.
} 
Second, because RPSs might have different levels of stringency we wanted to test whether our results were robust for these different types of RPSs. We therefore categorized RPSs into two categories. The first one represents RPSs with the requirement to build new capacity in state. The second category represents RPSs without such requirements. Tables A5 and A6 in the Appendix provide the results of the two stage regressions. Overall, the results show that both types of RPS policies have a negative and insignificant effect on renewable capacity. However, the effect is significant and positive for the interaction term between RPS with requirements and investor owned utilities. Third, we wanted to test whether there would be an additive effect of renewable policies. We conducted an additional analysis with a variable that represents the number of different renewable policies implemented by a state. This variable is insignificant in all models, indicating that there is no additive value to the policies and the possibility that policies might cancel each other. $^{23}$

\section{Discussion and conclusion}

The purpose of this paper is to analyze the effects of two different state renewable energy policies Renewable Portfolio Standards and Mandatory Green Power Options on installed renewable energy capacity. Our results show varied effects of the policies. RPS has proven to have a negative effect on invest ments in renewable capacity. Our results differ therefore from previous studies that found RPS to be effective at increasing installed wind capacity (Bird et al., 2005; Menz and Vachon, 2006; Yin and Powers, 2010) and show the importance of modeling the context of policy adoption to avoid sample selection bias. Furthermore, the effect of RPS on investments in renewables changes in our model when we include an interaction term between RPS and investor owned utilities. The result is a positive and significant effect, demonstrating that investor owned utilities respond more to the implementation of RPS than do publicly owned utilities.

As expected, the effect of the more market oriented policy Mandatory Green Power Option proved to be positive and significant. Specifically, our results show that MGPO, which requires utilities to provide green electricity to their customers, has proven effective in increasing installed renewable capacity. We also found that the variable for green residential customers provided positive and significant results. Essentially, the more the customers willing to pay a premium for green electricity, the greater the installed renewable capacity.

Our analysis differs from previous studies because this is the first paper to distinguish between utility ownership types, and thus provides further insight into the differentiated effect of the implementation of RPS on investor owned versus publicly owned electric utilities. Additionally, our green residential customers variable depicts the influential effect consumers can have upon installed capacity.

When analyzing the effect of resource potential, we found that solar and wind potential have a positive and significant impact on the adoption of renewable policies (at least RPS). However, resource potential was not significant in explaining installments of renewable capacity. Our results indicate that the relationship between natural resources, policies, and installed capacity can be complex. While higher natural resources endowment can facil itate the adoption of policies that are not effective, some effective policies might be adopted in states with low resource potential.

\footnotetext{
${ }^{23}$ Results available upon request from the authors.
}

Our results conclude therefore that factors other than natural resources can predict successful renewable policies. These factors include the social and political context in which the policy is implemented, the type of renewable policy, and the type of electric utility implementing it. Our findings indicate that a high presence of Sierra Club membership, green residential customers, and democratic representatives facilitate effective policies. These represent various communities that constitute an environment conducive to environmental conservation behavior highlighted in the literature (Kahn, 2007).

In determining the efficacy of these state renewable energy policies on installed capacity, it is critical to account for the lag time between the implementation of these policies and the installment of renewable capacity. The difficult question is: how much time must actually be accounted for in order to see a policy truly take effect? While we do observe a general trend of increased installments in renewable capacity over a ten year period (1997 2007), RPS remains a non significant variable despite using models with up to five year time lags between its implementation and installed capacity. It certainly is possible that a decade is not a sufficient period of time to see RPS take effect, because to this point it has not proved to be an influential factor on installed capacity.

It is also important to take into account our market findings, and the role of the market in affecting installed capacity. We find the variables for MGPO and green residential customers to be positive and significant, providing evidence that market mechan isms have the most substantial effect upon installed capacity. Thus, policies that influence the customer's ability to purchase green power, and the subsequent number of customers choosing to do so, have been a significant contributor to the rise in installed capacity over the last decade.

There are some recommendations that can be made regarding renewable policies based on our results. While we see that market mechanisms have a significant effect upon installed capacity, policies such as RPS, disclosure, and tax incentives have proven to be insignificant, which is problematic. Over the past decade, states have attempted to assume the responsibility that the federal government failed to take regarding national environ mental policies (Keeler, 2007). However, inherent aspects of these state policies such as flexibility clauses and the ability of utilities to employ out of state resources to meet renewable requirements for RPS make it difficult for these policies to truly make a difference (Keeler, 2007).

A potential solution to the problem could be incorporating the federal government in the renewable policy enactment and implementation process. The Clean Energy Group submitted a series of suggestions to the House of Representatives in 2007 regarding the interaction between state renewable policies and a federal RPS program. They recommend a federal RPS that assists states in reaching their RPS objectives, that sets a floor (but no ceiling) on renewable capacity across all states, and that builds off existing state and regional certificate tracking systems to allow for a synchronized use of RECs. ${ }^{24}$ While these suggestions seem credible, the Clean Energy Group's belief that "a well designed RPS would ideally apply equally to all load serving utilities" does not align with our findings. ${ }^{25}$ One difficulty with currently implemented RPS programs seems to be the differentiated response from investor owned and publicly owned utilities, and thus there should be differing requirements depending on the utility type. Indeed, moving from the state to the federal level

\footnotetext{
${ }^{24}$ Sinclair, Mark. Letter to Congressmen John D. Dingell and Rick Boucher. 14 June 2007. MS. Clean Energy Group, Montpelier, Vermont.

25 Sinclair, Mark. Letter to Congressmen John D. Dingell and Rick Boucher. 14 June 2007. MS. Clean Energy Group, Montpelier, Vermont.
} 
may pose a series of difficulties with aligning the patchwork of mandatory state policies into a coherent federal program (Keeler, 2007).

There is still further research to be done on the efficacy of state renewable policies on installed capacity. In order to determine the reasoning behind publicly and investor owned utilities' varied responses to renewable policies, further research should be conducted on specific firm level factors. A firm's management style and its business strategy should be analyzed, for these factors may influence a utility's decision to install renewable capacity or not. This information may in fact be critical in devising future state, and even federal policies so that they will have the greatest effect upon electric utilities. Further research could also identify whether specific policies are more effective at driving an increase in capacity for specific renewable energies (wind, solar, or biomass).

\section{Appendix}

See Tables A1 A6.

Table A1

Renewable policies and total electric capacity by state in 2007.

\begin{tabular}{|c|c|c|c|c|c|c|}
\hline State & RPS & MGPO & Disclosure & $\operatorname{Tax}^{\mathrm{a}}$ & Capacity (MW) & $\begin{array}{c}\text { Percentage of renewable } \\
\text { capacity (\%) }\end{array}$ \\
\hline Alabama & & & & & 30,614 & 1.87 \\
\hline Alaska & & & & & 1961 & $<1$ \\
\hline Arizona & $\mathrm{X}$ & & & $\mathrm{X}$ & 25,579 & 2.28 \\
\hline Arkansas & & & & & 15,296 & $<1$ \\
\hline California & $\mathrm{X}$ & & $\mathrm{X}$ & & 63,813 & 5.75 \\
\hline Colorado & $\mathrm{X}$ & $\mathrm{X}$ & $\mathrm{X}$ & $\mathrm{X}$ & 12,288 & 7.92 \\
\hline Connecticut & $\mathrm{X}$ & & $\mathrm{X}$ & $\mathrm{X}$ & 7725 & 2.56 \\
\hline Delaware & $\mathrm{X}$ & $\mathrm{X}$ & $\mathrm{X}$ & & 3357 & $<1$ \\
\hline Florida & & & $\mathrm{X}$ & $\mathrm{X}$ & 55,451 & 1.83 \\
\hline Georgia & & & & $\mathrm{X}$ & 36,472 & 1.79 \\
\hline Hawaii & $\mathrm{X}$ & & & $\mathrm{X}$ & 2436 & 7.97 \\
\hline Idaho & & & & $\mathrm{X}$ & 3196 & 5.71 \\
\hline Illinois & $\mathrm{X}$ & & $\mathrm{X}$ & $\mathrm{X}$ & 42,731 & 1.85 \\
\hline Indiana & & & & $\mathrm{X}$ & 27,021 & $<1$ \\
\hline Iowa & $\mathrm{X}$ & $\mathrm{X}$ & $\mathrm{X}$ & $\mathrm{X}$ & 12,287 & 8.85 \\
\hline Kansas & & & & $\mathrm{X}$ & 11,241 & 2.98 \\
\hline Kentucky & & & & $\mathrm{X}$ & 19,968 & $<1$ \\
\hline Louisiana & & & & $\mathrm{X}$ & 26,323 & 1.41 \\
\hline Maine & $\mathrm{X}$ & & $\mathrm{X}$ & $\mathrm{X}$ & 4213 & 17.91 \\
\hline Maryland & $\mathrm{X}$ & & $\mathrm{X}$ & $\mathrm{X}$ & 12,486 & 1.14 \\
\hline Massachusetts & $\mathrm{X}$ & & $\mathrm{X}$ & $\mathrm{X}$ & 13,557 & 2.46 \\
\hline Michigan & & & $\mathrm{X}$ & $\mathrm{X}$ & 30,305 & 1.27 \\
\hline Minnesota & $\mathrm{X}$ & & $\mathrm{X}$ & $\mathrm{X}$ & 12,890 & 11.33 \\
\hline Mississippi & & & & & 16,204 & 1.23 \\
\hline Missouri & & & & $\mathrm{X}$ & 20,558 & $<1$ \\
\hline Montana & $\mathrm{X}$ & $\mathrm{X}$ & & $\mathrm{X}$ & 5479 & 3.75 \\
\hline Nebraska & & & & $\mathrm{X}$ & 6971 & 1.09 \\
\hline Nevada & $\mathrm{X}$ & & $\mathrm{X}$ & $\mathrm{X}$ & 9954 & 3.37 \\
\hline New Hampshire & $\mathrm{X}$ & & & $\mathrm{X}$ & 4280 & 4.23 \\
\hline New Jersey & $\mathrm{X}$ & & $\mathrm{X}$ & $\mathrm{X}$ & 18,352 & 1.23 \\
\hline New Mexico & $\mathrm{X}$ & $\mathrm{X}$ & & $\mathrm{X}$ & 7202 & 6.31 \\
\hline New York & $\mathrm{X}$ & & $\mathrm{X}$ & $\mathrm{X}$ & 39,121 & 2.01 \\
\hline North Carolina & $\mathrm{X}$ & & & $\mathrm{X}$ & 27,644 & 1.24 \\
\hline North Dakota & $\mathrm{X}$ & & & $\mathrm{X}$ & 5091 & 7.35 \\
\hline Ohio & & & $\mathrm{X}$ & $\mathrm{X}$ & 33,755 & $<1$ \\
\hline Oklahoma & & & & $\mathrm{X}$ & 19,962 & 3.56 \\
\hline Oregon & $\mathrm{X}$ & $\mathrm{X}$ & $\mathrm{X}$ & $\mathrm{X}$ & 13,209 & 9.00 \\
\hline Pennsylvania & $\mathrm{X}$ & & $\mathrm{X}$ & $\mathrm{X}$ & 45,106 & 1.70 \\
\hline Rhode Island & $\mathrm{X}$ & & $\mathrm{X}$ & $\mathrm{X}$ & 1782 & 1.29 \\
\hline South Carolina & & & & $\mathrm{X}$ & 23,566 & 10.06 \\
\hline South Dakota & & & & $\mathrm{X}$ & 2870 & 1.38 \\
\hline Tennessee & & & & $\mathrm{X}$ & 20,861 & $<1$ \\
\hline Texas & $\mathrm{X}$ & & $\mathrm{X}$ & $\mathrm{X}$ & 101,938 & 4.28 \\
\hline Utah & & & & $\mathrm{X}$ & 7122 & $<1$ \\
\hline Vermont & $\mathrm{X}$ & & & $\mathrm{X}$ & 1111 & 8.35 \\
\hline Virginia & & & $\mathrm{X}$ & $\mathrm{X}$ & 22,992 & 2.94 \\
\hline Washington & $\mathrm{X}$ & $\mathrm{X}$ & $\mathrm{X}$ & $\mathrm{X}$ & 28,615 & 5.27 \\
\hline West Virginia & & & & $\mathrm{X}$ & 16,099 & $<1$ \\
\hline Wisconsin & $\mathrm{X}$ & & & $\mathrm{X}$ & 16,365 & 2.19 \\
\hline Wyoming & & & & $\mathrm{X}$ & 6667 & 4.08 \\
\hline
\end{tabular}

a Tax column includes corporate, sales, and property taxes. An " $\mathrm{X}$ " demonstrates that a state has implemented at least one of these taxes. 
Table A2

Description of the variables.

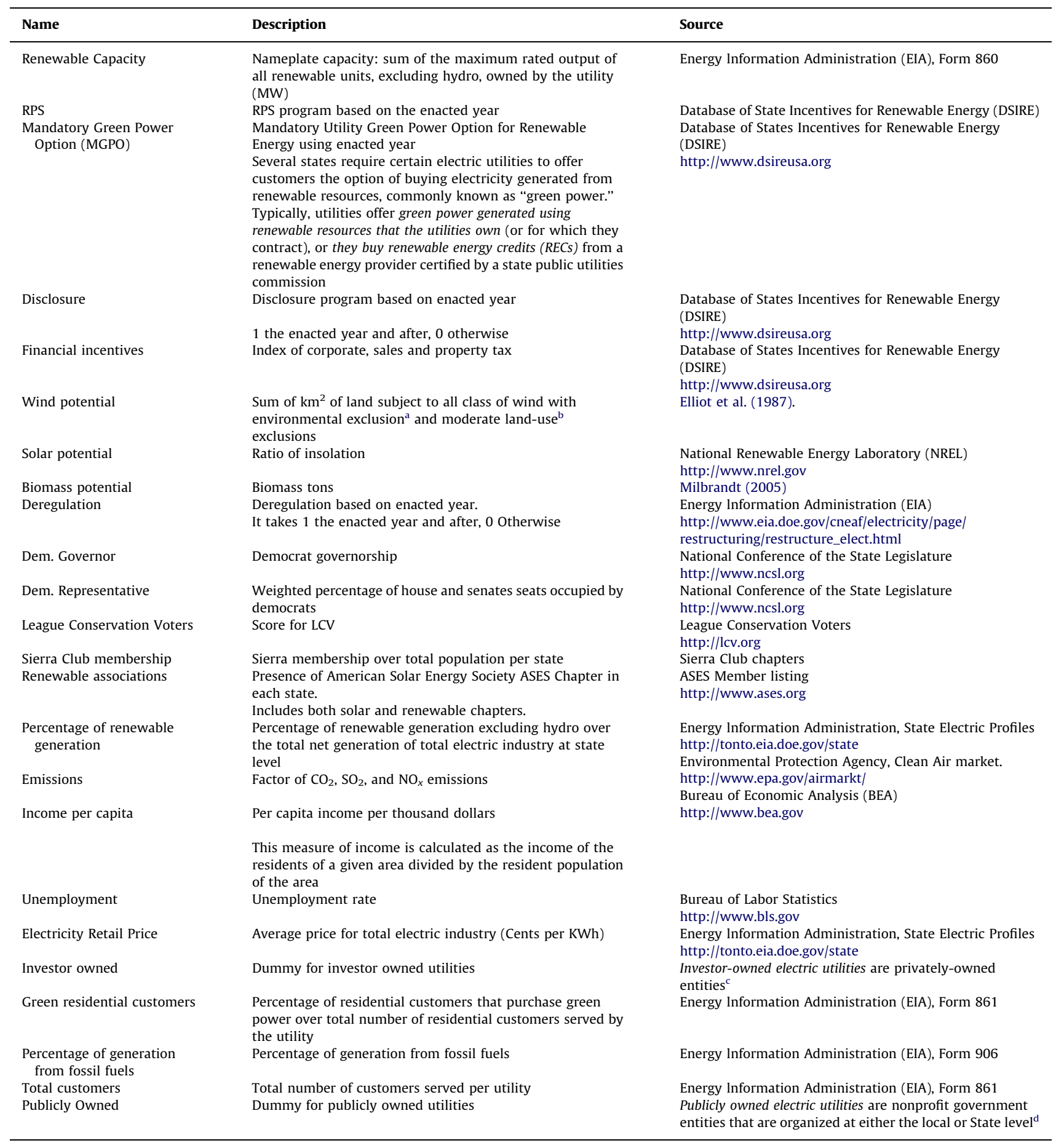

a Environmental exclusion areas are defined to largely represent natural areas including parks, monuments, wilderness areas, ecological preserves, and wildlife refuges where industrial, commercial, and residential developments are restricted or very 1 imited.

${ }^{\mathrm{b}}$ Land-use exclusion considers the 11 land-use types: (1) agricultural land; (2) range land; (3) mixed agricultural and range land; (4) deciduous forest ; (5) coniferous forest; (6) mixed forest; (7) urban land; (8) barren land; (9) nonforested wetland, (10) water; and (11) open, low scrub land.

${ }^{c}$ EIA website: investor owned utilities represent $6 \%$ of the total number of electric utilities and approximately $38 \%$ of utility installed capacity, $42 \%$ of generation, $66 \%$ of sales, and $67 \%$ of revenue in the U.S.

d EIA website: publicly owned utilities are 2009 publicly owned electric utilities in the U.S. They represent about $61 \%$ of the number of electric utilities, supply approximately $9 \%$ of generating capability, $8 \%$ of generation, and account for about $15 \%$ of retail sales and $13 \%$ of revenue. 
Table A3

Descriptive statistics and correlation matrix of the variables used in the Renewable Portfolio Standard analysis.

\begin{tabular}{|c|c|c|c|c|c|c|c|c|c|c|c|c|c|c|c|c|c|c|c|}
\hline & & Mean & SD & 1 & 2 & 3 & 4 & 5 & 6 & 7 & 8 & 9 & 10 & 11 & 12 & 13 & 14 & 15 & 16 \\
\hline 1 & RPS & 0.25 & 0.43 & & & & & & & & & & & & & & & & \\
\hline 2 & MGPO & 0.05 & 0.22 & 0.21 & & & & & & & & & & & & & & & \\
\hline 3 & Disclosure & 0.30 & 0.46 & 0.39 & 0.07 & & & & & & & & & & & & & & \\
\hline 4 & Wind resources & 7.39 & 3.23 & 0.23 & 0.18 & 0.07 & & & & & & & & & & & & & \\
\hline 5 & Solar resources & 19.15 & 2.74 & -0.01 & 0.02 & -0.23 & 0.09 & & & & & & & & & & & & \\
\hline 6 & Biomass resources & 8.50 & 1.31 & -0.20 & 0.00 & -0.05 & 0.03 & -0.09 & & & & & & & & & & & \\
\hline 7 & Deregulation & 0.34 & 0.47 & 0.24 & 0.03 & 0.52 & 0.11 & -0.24 & -0.28 & & & & & & & & & & \\
\hline 8 & Democratic governor & 0.44 & 0.54 & 0.01 & 0.10 & 0.04 & -0.15 & -0.18 & 0.12 & -0.09 & & & & & & & & & \\
\hline 9 & $\begin{array}{l}\text { Democratic } \\
\text { representative }\end{array}$ & 50.74 & 14.75 & 0.16 & -0.03 & 0.08 & -0.34 & -0.15 & -0.13 & 0.18 & 0.05 & & & & & & & & \\
\hline 10 & $\begin{array}{l}\text { League of } \\
\text { Conservation Voters }\end{array}$ & 43.81 & 27.53 & 0.37 & 0.01 & 0.41 & 0.01 & -0.50 & -0.27 & 0.29 & 0.09 & 0.37 & & & & & & & \\
\hline 11 & Sierra membership & 1.94 & 1.18 & 0.32 & 0.17 & 0.40 & 0.08 & -0.14 & -0.28 & 0.19 & 0.16 & 0.07 & 0.45 & & & & & & \\
\hline 12 & $\begin{array}{l}\text { Renewable } \\
\text { associations }\end{array}$ & 0.68 & 0.47 & 0.36 & 0.02 & 0.43 & -0.20 & -0.09 & -0.09 & 0.31 & 0.15 & 0.23 & 0.37 & 0.44 & & & & & \\
\hline 13 & $\begin{array}{l}\text { Percent of electricity } \\
\text { generated from } \\
\text { renewables }\end{array}$ & 2.49 & 4.04 & 0.25 & -0.07 & 0.22 & -0.06 & -0.22 & -0.06 & 0.17 & 0.34 & 0.13 & 0.30 & 0.34 & 0.24 & & & & \\
\hline 14 & Emissions & 0.08 & 1.67 & -0.13 & -0.14 & 0.06 & -0.21 & -0.04 & 0.40 & -0.03 & -0.08 & 0.01 & -0.24 & -0.41 & 0.04 & -0.25 & & & \\
\hline 15 & Income per capita & 28.22 & 5.23 & 0.47 & 0.04 & 0.65 & 0.11 & -0.27 & -0.21 & 0.40 & -0.02 & 0.04 & 0.45 & 0.43 & 0.40 & 0.06 & -0.14 & & \\
\hline 16 & Unemployment & 4.97 & 1.33 & -0.12 & -0.02 & 0.00 & -0.19 & 0.17 & 0.07 & -0.08 & 0.02 & 0.16 & -0.04 & 0.13 & 0.11 & 0.01 & 0.15 & -0.23 & \\
\hline 17 & Electricity retail price & 6.95 & 1.97 & 0.39 & -0.08 & 0.40 & -0.07 & -0.28 & -0.35 & 0.48 & -0.01 & 0.27 & 0.58 & 0.45 & 0.50 & 0.44 & 0.20 & 0.54 & -0.06 \\
\hline
\end{tabular}

$N$ 480. The states of Alaska and Hawaii are not included in the analysis due to lack of data on natural resources. Correlations with values equal or greater than 0.09 are significant at $5 \%$ (in bold).

Table A4a

Descriptive statistics of the variable used in the renewable capacity model analysis.

\begin{tabular}{|c|c|c|}
\hline & Mean & SD \\
\hline Renewable capacity & 0.01 & 0.10 \\
\hline RPS & 0.32 & 0.46 \\
\hline MPGO & 0.09 & 0.28 \\
\hline Disclosure & 0.40 & 0.49 \\
\hline Financial incentives & 0.91 & 0.86 \\
\hline Wind resources & 8.75 & 2.93 \\
\hline Solar resources & 19.52 & 2.68 \\
\hline Biomass resources & 9.23 & 1.07 \\
\hline Deregulation & 0.27 & 0.44 \\
\hline Democratic governor & 45.85 & 52.92 \\
\hline Democratic representative & 48.12 & 11.43 \\
\hline League of Conservation Voters & 41.25 & 24.48 \\
\hline Sierra membership & 1.90 & 1.17 \\
\hline Renewable associations & 0.78 & 0.41 \\
\hline Percent of electricity generated from renewables & 2.07 & 2.75 \\
\hline Emissions & 0.08 & 1.58 \\
\hline Income per capita & 29.69 & 4.63 \\
\hline Unemployment & 4.67 & 1.20 \\
\hline Electricity retail price & 6.87 & 1.75 \\
\hline Investor owned & 0.20 & 0.40 \\
\hline Green residential customers & 0.12 & 0.72 \\
\hline Percent of generation from fossil fuel & 0.82 & 0.35 \\
\hline Total customers & 0.16 & 0.49 \\
\hline
\end{tabular}




\begin{tabular}{|c|c|c|c|c|c|c|c|c|c|c|c|c|c|c|}
\hline 1 & Renewable capacity & & & & & & & & & & & & & \\
\hline 2 & RPS & 0.04 & & & & & & & & & & & & \\
\hline 3 & MPGO & 0.00 & 0.37 & & & & & & & & & & & \\
\hline 4 & Disclosure & 0.06 & 0.27 & 0.21 & & & & & & & & & & \\
\hline 5 & Financial incentives & -0.03 & 0.44 & 0.14 & 0.24 & & & & & & & & & \\
\hline 6 & Wind resources & 0.00 & 0.31 & 0.18 & -0.06 & 0.16 & & & & & & & & \\
\hline 7 & Solar resources & 0.02 & -0.26 & -0.07 & -0.38 & -0.31 & 0.24 & & & & & & & \\
\hline 8 & Biomass resources & 0.02 & 0.17 & 0.24 & -0.01 & 0.02 & 0.30 & -0.07 & & & & & & \\
\hline 9 & Deregulation & -0.01 & -0.06 & -0.18 & 0.56 & 0.09 & -0.09 & -0.30 & -0.26 & & & & & \\
\hline 10 & Democratic governor & 0.00 & 0.15 & 0.31 & 0.05 & 0.03 & 0.03 & -0.13 & 0.21 & -0.14 & & & & \\
\hline 11 & Democratic representative & 0.03 & 0.19 & -0.02 & 0.16 & -0.07 & -0.18 & -0.30 & -0.13 & 0.25 & 0.01 & & & \\
\hline 12 & League of Conservation Voters & 0.06 & 0.34 & 0.04 & 0.43 & 0.13 & -0.17 & -0.63 & -0.17 & 0.29 & 0.09 & 0.40 & & \\
\hline 13 & Sierra membership & 0.12 & 0.37 & 0.12 & 0.46 & 0.15 & 0.03 & -0.22 & -0.26 & 0.09 & 0.12 & 0.24 & 0.59 & \\
\hline 14 & Renewable associations & 0.03 & 0.36 & 0.16 & 0.41 & 0.30 & -0.05 & -0.31 & 0.08 & 0.24 & 0.19 & 0.05 & 0.40 & 0.35 \\
\hline 15 & Percent of electricity generated from renewables & 0.14 & 0.29 & 0.09 & 0.29 & 0.03 & -0.10 & -0.18 & -0.09 & 0.07 & 0.16 & 0.30 & 0.45 & 0.55 \\
\hline 16 & Emissions & -0.01 & -0.15 & -0.18 & 0.19 & 0.20 & -0.31 & -0.21 & 0.16 & 0.32 & -0.17 & -0.12 & -0.10 & -0.35 \\
\hline 17 & Income per capita & 0.05 & 0.33 & 0.07 & 0.56 & 0.25 & 0.10 & -0.30 & -0.03 & 0.26 & 0.05 & 0.14 & 0.40 & 0.45 \\
\hline 18 & Unemployment & 0.04 & -0.23 & -0.05 & 0.23 & -0.09 & -0.24 & -0.03 & -0.09 & 0.26 & 0.06 & 0.07 & 0.11 & 0.16 \\
\hline 19 & Electricity retail price & 0.09 & 0.21 & -0.09 & 0.43 & 0.14 & -0.16 & --0.17 & -0.37 & 0.42 & -0.04 & 0.39 & 0.51 & 0.47 \\
\hline 20 & Investor owned & 0.12 & -0.03 & -0.12 & 0.02 & -0.05 & -0.20 & -0.13 & -0.19 & 0.16 & -0.03 & 0.09 & 0.09 & 0.00 \\
\hline 21 & Green residential customers & 0.02 & 0.16 & 0.09 & 0.14 & 0.09 & 0.07 & -0.06 & 0.06 & -0.09 & 0.05 & 0.00 & 0.08 & 0.22 \\
\hline 22 & Percent of generation from fossil fuel & -0.09 & 0.08 & 0.00 & -0.06 & 0.10 & 0.13 & 0.15 & 0.32 & -0.07 & 0.00 & 0.02 & -0.27 & -0.32 \\
\hline \multirow[t]{2}{*}{23} & Total customers & 0.41 & -0.03 & -0.08 & 0.12 & -0.09 & -0.11 & -0.01 & -0.07 & 0.13 & -0.02 & 0.07 & 0.07 & 0.08 \\
\hline & & & 14 & 15 & & 16 & 17 & 18 & & 19 & 20 & & & 22 \\
\hline 1 & Renewable capacity & & & & & & & & & & & & & \\
\hline 2 & RPS & & & & & & & & & & & & & \\
\hline 3 & MPGO & & & & & & & & & & & & & \\
\hline 4 & Disclosure & & & & & & & & & & & & & \\
\hline 5 & Financial incentives & & & & & & & & & & & & & \\
\hline 6 & Wind resources & & & & & & & & & & & & & \\
\hline 7 & Solar resources & & & & & & & & & & & & & \\
\hline 8 & Biomass resources & & & & & & & & & & & & & \\
\hline 9 & Deregulation & & & & & & & & & & & & & \\
\hline 10 & Democratic governor & & & & & & & & & & & & & \\
\hline 11 & Democratic representative & & & & & & & & & & & & & \\
\hline 12 & League of Conservation Voters & & & & & & & & & & & & & \\
\hline 13 & Sierra membership & & & & & & & & & & & & & \\
\hline 14 & Renewable associations & & & & & & & & & & & & & \\
\hline 15 & Percent of electricity generated from renewables & & 0.27 & & & & & & & & & & & \\
\hline 16 & Emissions & & 0.13 & -0.26 & & & & & & & & & & \\
\hline 17 & Income per capita & & 0.35 & 0.20 & & -0.14 & & & & & & & & \\
\hline 18 & Unemployment & & 0.22 & 0.10 & & 0.25 & 0.00 & & & & & & & \\
\hline 19 & Electricity retail price & & 0.35 & 0.46 & & -0.04 & 0.48 & 0.17 & & & & & & \\
\hline 20 & Investor owned & & 0.15 & 0.07 & & 0.16 & -0.02 & 0.12 & & 0.15 & & & & \\
\hline 21 & Green residential customers & & 0.07 & 0.11 & & -0.08 & 0.15 & 0.03 & & 0.02 & 0.01 & & & \\
\hline 22 & Percent of generation from fossil fuel & & -0.02 & -0.24 & & 0.14 & -0.01 & -0.14 & & -0.13 & -0.15 & & .02 & \\
\hline 23 & Total customers & & 0.13 & 0.09 & & 0.13 & 0.05 & 0.13 & & 0.20 & 0.57 & & .03 & -0.16 \\
\hline
\end{tabular}

$N$ 5807. Correlations with values equal or greater than 0.03 are significant at $5 \%$. 
Table A5

Multinomial Logit Model of the adoption of Renewable Portfolio Standards with and without requirements of building new capacity.

\begin{tabular}{|c|c|c|c|}
\hline Reference group & $\begin{array}{l}\text { RPS without } \\
\text { requirement } \\
\text { No RPS }\end{array}$ & $\begin{array}{l}\text { RPS with } \\
\text { requirement } \\
\text { No RPS }\end{array}$ & $\begin{array}{l}\text { RPS with } \\
\text { requirement } \\
\text { RPS without } \\
\text { requirement }\end{array}$ \\
\hline Disclosure & $\begin{array}{l}-0.09 \\
(1.61)\end{array}$ & $\begin{array}{c}-1.18 \\
(1.00)\end{array}$ & $\begin{array}{c}-1.08 \\
(1.46)\end{array}$ \\
\hline Wind resources & $\begin{array}{l}-0.04 \\
(0.46)\end{array}$ & $\begin{array}{l}1.22^{* *} \\
(0.52)\end{array}$ & $\begin{array}{l}1.26^{*} \\
(0.76)\end{array}$ \\
\hline Solar resources & $\begin{array}{l}3.40^{* * *} \\
(0.72)\end{array}$ & $\begin{array}{l}0.38 \\
(0.38)\end{array}$ & $\begin{array}{l}-3.02^{* * *} \\
(0.71)\end{array}$ \\
\hline Biomass resources & $\begin{array}{l}-13.71^{* * *} \\
(2.88)\end{array}$ & $\begin{array}{l}-0.40 \\
(0.44)\end{array}$ & $\begin{array}{l}13.31^{* * *} \\
(2.87)\end{array}$ \\
\hline Deregulation & $\begin{array}{l}7.01^{* * *} \\
(2.40)\end{array}$ & $\begin{array}{l}1.11 \\
(1.00)\end{array}$ & $\begin{array}{l}-5.90^{* * *} \\
(2.22)\end{array}$ \\
\hline Democratic governor & $\begin{array}{l}2.21 \\
(1.73)\end{array}$ & $\begin{array}{l}0.39 \\
(0.55)\end{array}$ & $\begin{array}{l}-1.82 \\
(1.60)\end{array}$ \\
\hline Democratic representative & $\begin{array}{l}-0.04 \\
(0.07)\end{array}$ & $\begin{array}{l}0.04 \\
(0.03)\end{array}$ & $\begin{array}{l}0.08 \\
(0.06)\end{array}$ \\
\hline League Conservation Voters & $\begin{array}{l}0.02 \\
(0.09)\end{array}$ & $\begin{array}{l}0.08^{* * * *} \\
(0.02)\end{array}$ & $\begin{array}{l}0.06 \\
(0.09)\end{array}$ \\
\hline Sierra membership & $\begin{array}{l}9.44^{* * * *} \\
(1.82)\end{array}$ & $\begin{array}{l}-0.38 \\
(0.49)\end{array}$ & $\begin{array}{l}-9.82^{* * *} \\
(1.82)\end{array}$ \\
\hline Renewable associations & $\begin{array}{l}22.27^{* * *} \\
(5.03)\end{array}$ & $\begin{array}{l}7.08^{* * * *} \\
(2.56)\end{array}$ & $\begin{array}{l}-15.19^{* * *} \\
(5.31)\end{array}$ \\
\hline $\begin{array}{l}\text { Percent of electricity } \\
\text { generated from } \\
\text { renewables }\end{array}$ & $\begin{array}{l}1.97^{* * *} \\
(0.41)\end{array}$ & $\begin{array}{l}0.10 \\
(0.07)\end{array}$ & $\begin{array}{l}-1.87^{* * *} \\
(0.41)\end{array}$ \\
\hline Emissions & $\begin{array}{l}10.90^{* * *} \\
(2.10)\end{array}$ & $\begin{array}{l}0.46^{*} \\
(0.24)\end{array}$ & $\begin{array}{l}-10.44^{* * * *} \\
(2.15)\end{array}$ \\
\hline Income per capita & $\begin{array}{l}2.15^{\text {**** }} \\
(0.54)\end{array}$ & $\begin{array}{l}0.11 \\
(0.16)\end{array}$ & $\begin{array}{l}-2.04^{* * *} \\
(0.55)\end{array}$ \\
\hline Unemployment & $\begin{array}{l}-2.36^{* *} \\
(1.00)\end{array}$ & $\begin{array}{l}-1.77^{* * *} \\
(0.42)\end{array}$ & $\begin{array}{l}0.59 \\
(1.05)\end{array}$ \\
\hline Electricity retail price & $\begin{array}{l}-2.21^{* * *} \\
(0.80)\end{array}$ & $\begin{array}{l}0.13 \\
(0.23)\end{array}$ & $\begin{array}{l}2.33^{* * * *} \\
(0.81)\end{array}$ \\
\hline Constant & $\begin{array}{l}-52.98^{* * *} \\
(17.61)\end{array}$ & $\begin{array}{l}-24.21^{* * *} \\
(9.24)\end{array}$ & $\begin{array}{l}28.77^{*} \\
(17.36)\end{array}$ \\
\hline $\begin{array}{l}\text { Observations } \\
\text { Pseudo } R^{2}\end{array}$ & $\begin{array}{l}480 \\
0.687\end{array}$ & $\begin{array}{l}480 \\
0.687\end{array}$ & $\begin{array}{l}480 \\
0.687\end{array}$ \\
\hline
\end{tabular}

Year dummies are included in all models, but are not reported.

$$
\begin{aligned}
& { }^{*} p<0.1 . \\
& { }^{* * *} p<0.05 . \\
& { }^{* * *} p<0.01 .
\end{aligned}
$$

\section{Table A6}

Tobit Model of Renewable Capacity (1998-2007) using enacted RPS year with and without requirements of building new capacity.

\begin{tabular}{|c|c|}
\hline & Renewable Capacity \\
\hline Deregulation & $\begin{array}{l}-0.13 \\
(0.08)\end{array}$ \\
\hline Democratic governor & $\begin{array}{l}0.00 \\
(0.00)\end{array}$ \\
\hline Democratic representative & $\begin{array}{l}0.01^{* *} \\
(0.00)\end{array}$ \\
\hline League conservation voters & $\begin{array}{l}0.00 \\
(0.00)\end{array}$ \\
\hline Sierra membership & $\begin{array}{l}0.10^{* * *} \\
(0.04)\end{array}$ \\
\hline Renewable association & $\begin{array}{l}-0.03 \\
(0.05)\end{array}$ \\
\hline Percent of electricity generated from renewables & $\begin{array}{l}0.01 \\
(0.01)\end{array}$ \\
\hline Emissions & $\begin{array}{l}-0.01 \\
(0.02)\end{array}$ \\
\hline Income per capita & $\begin{array}{l}-0.01 \\
(0.01)\end{array}$ \\
\hline Unemployment & $\begin{array}{l}-0.02 \\
(0.02)\end{array}$ \\
\hline Electricity retail price & $\begin{array}{l}-0.01 \\
(0.02)\end{array}$ \\
\hline Investor owned utilities & $\begin{array}{l}-0.05 \\
(0.09)\end{array}$ \\
\hline Green residential customers & $\begin{array}{l}0.03^{* *} \\
(0.01)\end{array}$ \\
\hline Percent of generation from fossil fuels & $\begin{array}{l}-0.12^{*} \\
(0.07)\end{array}$ \\
\hline Total customers & $\begin{array}{l}0.24^{* *} \\
(0.11)\end{array}$ \\
\hline Constant & $\begin{array}{l}-0.24 \\
(0.46)\end{array}$ \\
\hline Observations & 5807 \\
\hline Pseudo $R^{2}$ & 0.385 \\
\hline
\end{tabular}

\begin{tabular}{ll}
\hline & Renewable Capacity \\
\hline RSP without requirements & -0.19 \\
& $(0.14)$ \\
RSP with requirements & -0.08 \\
& $(0.07)$ \\
RSP without requirements $\times$ Investor & 0.42 \\
& $(0.33)$ \\
RSP with requirements $\times$ Investor & $0.38^{* * *}$ \\
& $(0.14)$ \\
MGPO & $0.20^{* * *}$ \\
& $(0.08)$ \\
Disclosure & -0.07 \\
Financial incentives & $(0.06)$ \\
Wind resources & -0.04 \\
Solar resources & $(0.04)$ \\
& -0.00 \\
Biomass resources & $(0.01)$ \\
\end{tabular}

Table A6 (continued)

Year dummies are included in all models, but are not reported.

$$
\begin{aligned}
& { }^{*} p<0.1 . \\
& { }^{* *} p<0.05 . \\
& { }^{* * *} p<0.01 .
\end{aligned}
$$

\section{References}

American Wind Energy Association, 1997. The Mechanics of a Renewables Portfolio Standard Applied at the State Level, November. <http://righg.raabassociates.org/ Articles/AWEA\%20State\%20RPS\%20Planning.doc $\rangle$.

Anton, W.R.Q., Deltas, G., Khanna, M., 2004. Incentives for environmental selfregulation and implications for environmental performance. Journal of Environmental Economics and Management 48 (1), 632-654.

Bergmann, A., Hanley, N., Wright, R., 2006. Valuing the attributes of renewable energy investments. Energy Policy 34, 1004-1014.

Bird, L., Swezey, B., 2003. Green Power Marketing in the United States: A Status Report, 6th Edition National Renewable Energy Laboratory, Golden, CO NREL/ TP-620-35119.

Bird, L., Bolinger, M., Gagliano, T., Wiser, R., Brown, M., Parsons, B., 2005. Policies and market factors driving wind power development in the United States. Energy Policy 33, 1397-1407.

Blamey, R., Bennett, J., Louviere, J., Morrison, M., Rolfe, J., 2000. A test of policy labels in environmental choice modeling studies. Ecological Economics 32 (2), 269-286.

Bonardi, J.P., Holburn, G., Vanden Bergh, R., 2006. Nonmarket strategy in regulated industries: theory and evidence from U.S. electric utilities. Academy of Management Journal 49 (6), 1209-1228.

Borchers, A.M., Duke, J.M.A, Parsons, G.R., 2007. Does willingness to pay for green energy differ by source? Energy Policy 35 (6), 3327-3334.

Byrnes, B., Jones, C., Goodman, S., 1999. Contingent valuation and real economic commitments: evidence from electricity utility green pricing programmes. Journal of Environmental Planning and Management 42, 149-166.

Carley, S., 2009. State renewable energy electricity policies: an empirical evaluation. Energy Policy 37, 3071-3081.

D’Agostino, R.B., Balanger, A., D’Agostino Jr., R.B., 1990. A suggestion for using powerful and informative tests of normality. The American Statistician 44 (4), 316-321.

Daly, H.E., 1996. Beyond Growth: The Economics of Sustainable Development. Beacon Press, Boston, MA 
Delmas, M., Tokat, Y., 2005. Deregulation, efficiency and governance structures the U.S. electric utility sector. Strategic Management Journal 26, 441-460.

Delmas, M., Russo, M., Montes-Sancho, M., 2007. Deregulation and environmenta differentiation in the electric utility industry. Strategic Management Journal 28 (2), 189-209.

Delmas, M., Shimshack, J., Montes-Sancho, M., 2010. Information disclosure policies: evidence from the electricity industry. Economic Inquiry 48 (2), 483-498.

Delmas, M.A., Montes, M.J., 2010. Voluntary agreements to improve environmental quality: symbolic and substantive cooperation. Strategic Management Journal 31 (6), 576-601.

Desvousges, W.H., Smith, V.K., Rink, H.H., 1992. Communicating radon risks effectively: the Maryland experience. Journal of Public Policy and Marketing 11 (2), 68-78

Ethier, R.G., Poe, G.L., Schulze, W.D., Clark, J., 2000. A comparison of hypothetical phone and mail contingent valuation responses for greenpricing electricity programs. Land Economics 76, 54-67.

Electric Power Industry Overview, 2007. Energy Information Administration. $\langle$ http://www.eia.doe.gov/cneaf/electricity/page/prim2/toc2.html〉.

Elliot, D.L., Wendell, L.L., Gower, G.L., 1987. An Assessment of the Available Windy Land Area and Wind Energy Potential in Contiguous United States. Pacific Northwest Laboratory operated for the US Department of Energy Battelle Memorial Institute.

Elliott, D.L., Schwartz, M.N., 1993. Wind Energy Potential in the United States. PNLSA 23109. Pacific Northwest Laboratory, Richland, WA NTIS no. DE94001667.

Fremeth, A. 2009. The Dynamic Relationship between Firm Capabilities, Regulatory Policy, and Corporate Environmentalism. Unpublished dissertation, University of Minnesota.

Gossling, S., Kunkel, T., Schumacher, K., Heck, N., Birkemeyer, J., Froese, J., Naber, N., Schliermann, E., 2005. A target group-specific approach to "green" power retailing: students as consumers of renewable energy. Renewable \& Sustainable Energy Reviews 9, 69-83.

Green, G.P., Fleischmann, A., Kwong, T.M., 1996. The effectiveness of local economic development policies in the 1980s. Social Science Quarterly 77 (3), 609-625.

Greene, W.H., 2008. Econometric Analysis, Fifth Edition Prenctice Hall.

Hamilton, J.T., 1997. Taxes, torts, and the toxics release inventory: congressional voting on instruments to control pollution. Economic Inquiry 35 (4), 745-762.

Heckman, J., 1978. Dummy endogenous variables in a simultaneous equation system. Econometrica 46 (6), 931-959.

Helland, E., 1998. Environmental protection in the federalist system: the political economy of NPDES inspections. Economic Inquiry 31 (2), 1465-7295.

Kahn, M.E., 2002. Demographic change and the demand for environmental regulation. Journal of Policy Analysis and Management 21 (1), 45-62.

Kassinis, G., Vafeas, N., 2002. Corporate boards and outside stakeholders as determinants of environmental litigation. Strategic Management Journal 23 (5), 399-415.

Kassinis, G., Vafeas, N., 2006. Stakeholder pressures and environmental performance. Academy of Management Journal 49 (1), 145-159.

Keeler, A.G., 2007. State greenhouse gas reduction policies: a move in the right direction? Policy Science 40, 353-365.

Kahn, M.E., 2007. Do greens drive Hummers or hybrids? Environmental ideology as a determinant of consumer choice. Journal of Environmental Economics and Management 54, 129-154.

Khanna, M., Damon, L., 1999. EPA's voluntary 33/50 program: impact on toxic releases and economic performance of firms. Journal of Environmental Economics and Management 37, 1-25.

King, A.A., Lenox, M.J., 2000. Industry self-regulation without sanctions: the chemical industry's Responsible Care Program. Academy of Management Journal 43 (4), 698-716.

Kim, E.-H., 2009. Does Competition Promote Environmental Investments? Retail Electricity Deregulation and Renewable Generation, Working paper.

Loureiro, M.L., Lotade, J., 2005. Do fair trade and eco-labels in coffee wake up the consumer conscience? Ecological Economics 53 (1), 129-138.

Loureiro, M.L., 2003. Rethinking new wines: implications of local and environmentally friendly labels. Food Policy 28 (5-6), 547-560.

Leire, C., Thidell, A., 2005. Product-related environmental information to guide consumer purchases-a review and analysis of research on perceptions, understanding and use among Nordic consumers. Journal of Cleaner Production 13 (10-11) 1061-1070.

Lubell, M., Schneider, M., Scholz, J.T., Mete, M., 2002. Watershed partnerships and the emergence of collective action institutions. American Journal of Political Science 46 (1), 148-163.
Lyon, T.P., Yin, H., 2010. Why do states adopt renewable portfolio standards?: An empirical investigation. The Energy Journal 31 (3), 131-155.

Maxwell, J.W., Lyon, T.P., Hackett, S.C., 2000. Self-regulation and social welfare: the political economy of corporate environmentalism. Journal of Law and Economics 43 (2), 583-617.

Menz, F.C., 2005. Green electricity policies in the United States: case study. Energy Policy 33, 2398-2410.

Menz, F., Vachon, S., 2006. The effectiveness of different policy regimes for promoting wind power: experiences from the states. Energy Policy 34 $1786-1796$.

Michaels, R.J., 2008. National Renewable Portfolio Standard: smart policy or misguided gesture? Energy Law Journal 29 (79), 79-119.

Milbrandt, A., 2005. Geographic Perspective on the Current Biomass Resource Availability in the United States. NREL Report No. TP-560-39181.

Pressman, J.L., Wildavsky, A., 1973. Implementation. University of California Press, Ltd., Los Angeles.

Riddel, M., 2003. Candidate eco-labeling and senate campaign contributions. Journal of Environmental Economics and Management 45 (2), 177-194.

Rivera, J., 2002. Assessing a voluntary environmental initiative in the developing world: The Costa Rican certification for sustainable tourism. Policy Sciences 35 (4), 333-360.

Rivera, J., DeLeon, P., 2004. Is greener whiter? The Sustainable Slopes Program and the voluntary environmental performance of western ski areas. Policy Studies Journal 32 (3), 417-437.

Roe, et al., 2001. US consumers' willingness to pay for green electricity. Energy Policy 29, 917-925.

Rossi, J., 2010. The limits of a National Renewable Portfolio Standard. Connecticut Law Review 42 (5), 1425-1450.

Royston, B., 1991. SG3.5: Comment on SG3.4 and an improved D'Agostino test. Stata Technical Bulletin 3, 23-24.

Russo, M.V., 2003. The emergence of sustainable industries: building on natural capital. Strategic Management Journal 24, 317-331.

Shapiro, S.S., Wilk, M.B., 1965. An analysis of variance test for normality (complete samples). Biometrika 55, 591-611.

Shapiro, S.S., Francia, R.S., 1972. An approximate analysis of variance test for normality. Journal of American Statistical Association 67, 215-216.

Sine, W., Lee, B., 2009. Tilting at windmills? The environmental movement and the emergence of the U.S. wind energy sector. Administrative Science Quarterly $54,123-155$.

Solsky, S.T., Bielenberg., A.C., 2004. State RPS—a regulatory wind incentive. Project Finance International 297, 67-70 Baker Botts LLP. 〈http://www.bakerbotts. com/fcwsite/otherfiles/sfx31.pdf $>$.

Union of Concerned Scientists, 2008. Renewable Energy Portfolio Standard Summary $\langle$ http://www.ucsusa.org/assets/documents/clean_energy/massachusetts.pdf $\rangle$.

Vachon, S., Menz, F.C., 2006. The role of social, political, and economic interests in promoting state green energy policies. Environmental Science and Policy 9, $652-662$.

Vandenberghe, V., Robin, S., 2004. Evaluating the effectiveness of private education across countries: a comparison of methods. Labour Economics 11 (4), 487-506.

Viscusi, W.K., Hamilton, J.T., 1999. Are risk regulators rational? Evidence from hazardous waste cleanup decisions. American Economic Review 89 (4), 1010-1027

Welch, E.W., Mazur, A., Bretschneider, S., 2000. Voluntary behavior by electric utilities: levels of adoption and contribution of the Climate Challenge Program to the reduction of carbon dioxide. Journal of Policy Analysis and Management 19 (3), 407-424.

Wiser, R., Barbose, G. 2008. Renewables Portfolio Standards in the United States: A Status Report with Data through 2007. Rep. Lawrence Berkeley National Laboratory.

Wiser, R.H., Fowlie, M., Holt, E.A., 2001. Public goods and private interests: understanding non-residential demand for green power. Energy Policy 29, 1085-1097.

Wiser, Ryan, Namovicz, Christopher, Gielecki, Mark, Smith, Robert, 2007. The experience with renewable portfolio standards in the United States. The Electricity Journal, 8-20.

Yin, $\mathrm{H}_{\text {. }}$ Powers, N., 2010. Do state renewable portfolio standards promote in-state renewable generation? Energy Policy 38 (2), 1140-1149.

Zarnikau, J., 2003. Consumer demand for 'green power' and energy efficiency. Energy Policy 31, 1661-1672. 